This PDF is a selection from an out-of-print volume from the National Bureau of Economic Research

Volume Title: Risk Aspects of Investment-Based Social Security Reform Volume Author/Editor: John Y. Campbell and Martin Feldstein, editors Volume Publisher: University of Chicago Press

Volume ISBN: 0-226-09255-0

Volume URL: http://www.nber.org/books/camp01-1

Publication Date: January 2001

Chapter Title: The Role of Real Annuities and Indexed Bonds in an Individual Accounts Retirement Program

Chapter Author: Jeffrey R. Brown, Olivia S. Mitchell, James M. Poterba

Chapter URL: http://www.nber.org/chapters/c10598

Chapter pages in book: (p. 321 - 370) 


\title{
The Role of Real Annuities and Indexed Bonds in an Individual Accounts Retirement Program
}

\author{
Jeffrey R. Brown, Olivia S. Mitchell, \\ and James M. Poterba
}

It is better to have a permanent income than to be fascinating.

-Oscar Wilde, The Model Millionaire: A Note of Admiration

The current U.S. social security system provides retirees with a real annuity during their retirement years. After a worker's primary insurance amount has been determined at the date of retirement, the purchasing power of social security benefits remains fixed for the balance of the individual's life. This is accomplished by indexing retirement benefits to annual changes in the consumer price index (CPI). Retirees are therefore insulated from inflation risk, at least as long as their consumption bundle is not too different from the bundle used to compute the CPI.

Several current reform plans propose to supplement, or partially replace, the existing defined-benefit social security system with mandatory individual defined-contribution accounts. These plans are discussed in Gramlich (1996), Mitchell, Myers, and Young (1999), and NASI (1998). In most "individual account" plans, retirees would be required to purchase an annuity with all or part of their accumulated account balances. Yet the existing market for individual annuities in the United States is small, the expected present value of annuity payouts is typically below the

Jeffrey R. Brown is assistant professor of public policy at the Kennedy School of Government, Harvard University, and a faculty research fellow of the National Bureau of Economic Research. Olivia S. Mitchell is the International Foundation of Employee Benefit Plans Professor of Insurance and Risk Management at the Wharton School, University of Pennsylvania, and a research associate of the National Bureau of Economic Research. James M. Poterba is the Mitsui Professor of Economics at the Massachusetts Institute of Technology and director of the Public Economics Program at the National Bureau of Economic Research.

The authors thank Leemore Dafny and especially Amy Finkelstein for outstanding research assistance. They thank Joseph Bellersen, Brett Hammond, Eugene Strum, participants in an NBER preconference, and especially John Campbell and Mark Warshawsky for helpful discussions. The National Science Foundation and the National Institute on Aging (Brown and Poterba), the Pension Research Council at the Wharton School (Mitchell), and the National Bureau of Economic Research provided research support. 
purchase price of the annuity, and virtually all annuities currently available offer nominal rather than real payout streams. This has led some to argue that individual account plans would expose retirees to inflation risk that they do not currently face. If individuals purchase nominal annuities with their accumulated funds and the inflation rate is positive during their payout period, then the real value of their annuity payouts will decline over time. Even if inflation was expected to be positive at the time of the annuity purchase, some individuals may not recognize this, and they may experience an unexpected decline in real payouts. This effect is distinct from the inflation risk that arises from differences between expected and actual inflation rates.

In this paper, we explore four issues concerning real annuities, nominal annuities, and the inflation risks faced by prospective retirees, all of which are relevant to the prospects for individual accounts under social security reform. We begin by describing the annuity market in the United Kingdom. Annuitants in the United Kingdom can select from a wide range of both real and nominal annuity products. The U.K. annuity market demonstrates the feasibility of offering real annuities in the private marketplace. Moreover, the current U.K. annuity market may indicate the direction in which the U.S. annuity market will evolve since indexed bonds promising a fixed real return to investors have been available in the United Kingdom for nearly two decades. The availability of such bonds has made it possible for U.K. insurers to offer real annuity products without bearing inflation risk. Similar bonds have been available in the United States for only two years. Our evaluation of the U.K. annuity market includes an analysis of the relative prices of both real and nominal annuities, and we present estimates of how much a potential annuitant must pay to purchase the inflation insurance provided by a real annuity.

Next, we turn to the annuity market in the United States and investigate the availability of real annuities in this country. In early 1997, the U.S. government introduced Treasury inflation-protection securities (TIPS), and, since then, two products that might be described as inflation-indexed annuities have come to market. One, offered by the Irish Life Company of North America (ILONA), promises a constant-purchasing-power stream of benefits. Although this product offers buyers a real stream of annuity payouts, there have been no sales to date. The second, offered by TIAACREF, is a variable-payout annuity with payouts linked to returns on the CREF index-linked bond account. We describe the operation of the latter account in some detail and explain why, in practice, the TIAA-CREF variable annuity is not an inflation-indexed annuity. Our analysis of these two products suggests that no commercially significant real annuities are currently available in the U.S. annuity market.

We then consider whether a retiree could use a portfolio of stocks or bonds, in lieu of a portfolio of indexed bonds, to hedge long-term inflation risk. Specifically, we evaluate how much inflation risk annuitants would 
bear if, instead of purchasing nominal annuities, they purchased variablepayout annuities with payouts linked to various asset portfolios. We assess the potential inflation protection provided by different variable-payout annuities using historical correlation patterns between inflation and nominal returns on stocks, bonds, and bills.

The final portion of the analysis explores the expected-utility consequences of annuitizing retirement resources in alternative ways. A stylized model is used to calculate the expected lifetime utility of a retiree who could purchase a nominal annuity, a real annuity, and a variable-payout equity-linked annuity. In the first and third cases, the retiree would bear some inflation risk. We calibrate this model using available estimates of risk aversion, mortality risks, and the stochastic structure of real returns on corporate stock. Our results suggest that, for plausible values of risk aversion, retirees would not pay very much for the opportunity to purchase a real rather than a nominal annuity. This finding is sensitive, however, to assumptions regarding the stochastic process for inflation. Very high expected inflation rates, or very high levels of inflation variability, can reverse this conclusion.

We also find that a variable-payout annuity with payouts linked to the returns on a portfolio of common stocks is more attractive than a real annuity for consumers with modest risk aversion. This result rests on assumptions about the expected return on stocks relative to riskless assets and hence must be viewed with some caution since there is substantial prospective uncertainty about expected stock returns. The finding nevertheless illustrates the potentially important role of variable-payout annuities as devices for annuitizing assets from individual accounts.

The paper is divided into five sections. Section 9.1 presents our findings on the real and nominal annuity markets in the United Kingdom. Section 9.2 describes two "inflation-linked annuities" offered in the United States. Section 9.3 reports our findings on the correlation between unexpected inflation and real returns on various financial assets and summarizes previous research on this relation. This section also presents evidence on the ex post real payout streams that would have been paid to retirees had they purchased variable-payout annuities at different dates over the last seventy years. Section 9.4 outlines our algorithm for evaluating the utility benefits of access to various types of annuity products. We link this work with the rapidly growing literature on lifetime portfolio allocation in the presence of risky asset returns and uncertain inflation. In a brief concluding section, we sketch directions for future work.

\subsection{The Market for Real Annuities in the United Kingdom}

We begin our analysis by describing the real annuity market in the United Kingdom since it provides important evidence on both the feasibility of providing real annuities through private insurers and the consumer 
costs of buying inflation insurance. We then calculate the expected present discounted value of payouts on real and nominal annuities currently available in the United Kingdom.

\subsubsection{The Current Structure of the U.K. Annuity Market}

Annuities providing a constant real payout stream are widely available in the United Kingdom. This is partly due to the fact that governmentissued indexed bonds have been available in the United Kingdom for nearly two decades. Insurance companies holding these bonds can largely hedge the price-level risk that is associated with offering annuity payouts denominated in real rather than in nominal terms. (Payouts on indexed bonds in the United Kingdom adjust to past inflation with a lag, which results in some residual price-level exposure for insurance companies offering real annuities.) Blake (1999) reports that insurers offering nominal annuities typically back them by holding nominal government bonds while those offering real annuities hold indexed bonds.

There are two segments of the individual annuity market in the United Kingdom, defined according to where funds used to purchase the annuity have been accumulated. One market segment involves annuities purchased with tax-qualified retirement funds; the other is focused on annuities purchased outside such plans. Qualified retirement plans in Britain include defined-benefit occupation pension schemes and personal pension plans (PPPs). Most occupation plans are defined-benefit plans, and the annuities that are paid out to their beneficiaries are not purchased in the individual annuity market. PPPs, available since 1988, are retirement-saving plans that are broadly similar to individual retirement accounts in the United States. (Prior to 1988, a similar type of plan was available only to selfemployed individuals.) Contributions to PPPs are tax deductible, and income on the assets held in such plans is not taxed until the funds are withdrawn. Budd and Campbell (1998) report that, in the early 1990s, roughly one-quarter of U.K. workers participated in a personal pension plan. These plans are likely to account for most of the purchases of qualified annuities since defined-contribution plans constitute a minority of U.K. occupation pensions.

Those who reach retirement age with assets in a defined-contribution occupation pension, or with assets in a personal pension plan, are legally required to annuitize at least part of their pension accumulation. For this reason, the U.K. market for annuities purchased with funds from qualified pension plans is known as the compulsory annuity market. In recent years, there has been some relaxation of the rules requiring annuitization. Currently, a retiree can withdraw up to one-quarter of a personal pension plan accumulation as a lump-sum distribution, and assets can be held in the PPP up to age seventy-five before they must be annuitized.

The U.K. annuity market also includes a second segment, which con- 
tains voluntarily purchased annuities. This is known as the "noncompulsory" market. In this second market segment, funds accumulated outside qualified retirement plans are used to purchase annuity products.

The demographic characteristics and mortality prospects of annuity buyers in the compulsory and noncompulsory markets are likely to differ. The set of people who purchase annuities in the voluntary market is likely to have better mortality prospects (i.e., longer life expectancies) than the U.K. population at large. In addition, workers who have PPPs or who are covered by defined-contribution occupation plans are probably not a random subset of the population. They may also have better longevity prospects than those of the population at large. Finkelstein and Poterba (1999) compare the U.K. compulsory and noncompulsory annuity markets and show that payouts as a fraction of premiums are somewhat lower in the noncompulsory market than in the compulsory market. This finding is consistent with the view that adverse selection among annuitants receiving employer pensions is less substantial than adverse selection among people buying individual annuities outside a retirement plan. Our analysis focuses on annuities offered in the "compulsory-annuity" marketplace.

The compulsory annuitization requirement for personal pension plans has created a substantial group of retirement-age individuals in the United Kingdom who must purchase an annuity. To service their needs, annuity brokers exist to help retirees obtain quotes on annuity products. We contacted several of these brokers and requested data on U.K. annuity prices and the terms of annuity contracts. We obtained data from a number of firms. While we have not established precisely how much of the annuity market our sample firms cover, our sample of insurance companies appears to include most of the major annuity providers.

To focus the discussion, we restrict our attention to nominal and inflation-linked single-life annuity products. Here, the term nominal is used to refer to values denominated in current pounds (or dollars), while real refers to inflation-corrected pounds or dollars. We analyze products offered by nine insurance companies offering retail price index (RPI)-linked single-life annuity policies and fourteen companies offering nominal single-life products. (By comparison, there are nearly one hundred insurance companies offering individual annuity products in the United States, according to A. M. Best's surveys.) We do not consider "graded" nominal annuity policies that offer a rising stream of nominal benefits over the life of the annuitant, with a prespecified nominal escalation rate. Graded annuities provide annuitants with a way of backloading the real value of payouts from their annuities, but they do not insure against inflation fluctuations as real annuities do. We focus our attention on policies that were available in late August 1998, and we consider annuities with a $£ 100,000$ purchase price (premium).

Table 9.1 reports mean monthly payouts for both nominal and RPI- 
Summary Statistics on Nominal and Real Annuities Available in the Compulsory Annuity Market in the United Kingdom, 1998

\begin{tabular}{|c|c|c|c|c|}
\hline \multirow[b]{2}{*}{ Annuity Buyer Characteristics } & \multicolumn{2}{|c|}{$\begin{array}{l}\text { Average Monthly Payout } \\
\text { for a } £ 100,000 \text { Annuity }\end{array}$} & \multicolumn{2}{|c|}{$\begin{array}{l}\text { Coefficient of Variation } \\
\text { for Annuity Prices }\end{array}$} \\
\hline & Nominal & Real & Nominal & Real \\
\hline Man, 60 years old & 666.20 & 476.35 & 4.26 & 6.09 \\
\hline Man, 65 years old & 754.80 & 563.20 & 3.36 & 6.29 \\
\hline Man, 70 years old & 872.94 & 679.50 & 2.88 & 6.31 \\
\hline Woman, 60 years old & 602.99 & 416.81 & 5.34 & 5.02 \\
\hline Woman, 65 years old & 666.88 & 482.70 & 4.27 & 4.49 \\
\hline Woman, 70 years old & 760.50 & 575.06 & 3.65 & 4.48 \\
\hline
\end{tabular}

Source: Authors' calculations based on data provided by U.K. annuity brokers. Reference date is 21 August 1998. Sample consists of fourteen large insurance companies that provide annuities. Data were provided by Annuity Direct, Ltd. All annuity products analyzed in this table offer a five-year guarantee period.

linked annuities for the firms in our sample. The first two columns show the sample average payout for each type of annuity. They indicate that the first-month payout on a real annuity is between 25 and 30 percent lower than the first-month payout on a nominal annuity. This reduction in initial benefits is sometimes cited as the reason why some consumers shy away from indexed annuities; later in the paper, we discuss a number of other potential explanations for consumer reluctance to purchase real annuities. The data also indicate differences in the ratio of nominal to real annuity payouts across age groups (real annuities are priced more favorably with rising age) and between men and women (real annuities are priced more favorably for men). These presumably reflect mortality-related differences in the expected duration of payouts under different annuity contracts.

We also see substantial variation in the annuity benefits paid by the different insurers, as was previously found for the U.S. annuity market by Mitchell, Poterba, Warshawsky, and Brown (hereafter MPWB) (1999). The third and fourth columns of table 9.1 report the coefficient of variation for monthly annuity payouts in both markets; here, we see that the pricing of indexed annuities varies more than that of nominal annuities. For five of the six "products" defined by the age and gender of the buyer, the coefficient of variation is greater for the real than for the nominal annuity. This may be due to the fact that the effective duration of a real annuity is longer than that of a nominal annuity so that the insurer's cost of providing a real annuity is more sensitive to future developments in mortality patterns. Explaining the observed price dispersion in annuity markets is an important task for future research.

\subsubsection{Evaluating the "Money's Worth" of Nominal and Real Annuities}

To evaluate the administrative and other costs associated with the individual annuities offered in the U.K. market, we compute the expected pres- 
ent discounted value (EPDV) of payouts for the average nominal and the average index-linked annuity. We compare this EPDV with the premium cost of the annuity to obtain a measure of the "money's worth" of the individual annuity. Warshawsky (1988), Friedman and Warshawsky (1988, 1990), and MPWB (1999) report results of “money's worth" calculations for annuities offered in the United States.

The formula used to calculate the EPDV of a nominal annuity with a monthly payout $A_{n}$, purchased by an individual of age $b$, is

$$
V_{b}\left(A_{n}\right)=\sum_{j=1}^{12 \cdot(115-b)} \frac{A_{n} \cdot P_{j}}{\prod_{k=1}^{j}\left(1+i_{k}\right)} .
$$

We assume that no annuity buyer lives beyond age 115 , and we truncate the annuity calculation after $12 \cdot(115-b)$ months. $P_{j}$ denotes the probability that an individual of age $b$ years at the time of the annuity purchase survives for at least $j$ months after buying the annuity. The variable $i_{k}$ denotes the one-month nominal interest rate $k$ months after the annuity purchase.

For a real annuity, equation (1) must be modified to recognize that the amount of the payout is time varying in nominal terms but fixed in real terms. The easiest way to handle this is to allow $A_{r}$ to denote the real monthly payout and to replace the nominal interest rates in the denominator of (1) with corresponding real interest rates. We use $r_{k}$ to denote the one-month real interest rate $k$ months after the annuity purchase. Such real interest rates can be constructed from the U.K. yield curve for indexlinked Treasury securities. The expression that we evaluate to compute the EPDV of a real annuity is

$$
V_{b}\left(A_{r}\right)=\sum_{j=1}^{12 \cdot(115-b)} \frac{A_{r} \cdot P_{j}}{\prod_{k=1}^{j}\left(1+r_{k}\right)} .
$$

We evaluate (1) and (2) using projected survival probabilities for the U.K. population as a whole. These mortality probabilities are compiled by H.M. Treasury. We use cohort mortality tables for those who reached age sixty, sixty-five, or seventy in 1998. We were not able to obtain mortality tables corresponding to the annuitant population. By using population mortality tables, we are in effect asking what the EPDV of the average annuity would be when viewed from the perspective of an average individual in the population. Of course, the average annuity buyer has a longer life expectancy than the average person in the population. Since a real annuity offers larger payouts near the end of life than a nominal annuity does, using a population rather than an annuitant mortality table overstates the effective cost of purchasing an inflation-indexed annuity relative to a nominal annuity.

Table 9.2 reports EPDV calculations for single-life annuities for men 
Table 9.2

Expected Present Discounted Value of Annuity Payouts for Nominal and Real Annuities Available in the Compulsory Annuity Market, United Kingdom, August 1998

\begin{tabular}{lcccccccc}
\hline & \multicolumn{3}{c}{ Nominal Annuity } & & \multicolumn{2}{c}{ Inflation-Indexed Annuity } \\
\cline { 2 - 4 } Characteristics of & $\begin{array}{c}\text { Average } \\
\text { Annuitant }\end{array}$ & $\begin{array}{c}\text { Highest } \\
\text { Phree }\end{array}$ & $\begin{array}{c}\text { Lowest } \\
\text { Three }\end{array}$ & & $\begin{array}{c}\text { Average } \\
\text { Payout }\end{array}$ & $\begin{array}{c}\text { Highest } \\
\text { Three }\end{array}$ & $\begin{array}{c}\text { Lowest } \\
\text { Three }\end{array}$ \\
\hline Male, 60 years old & .921 & .953 & .873 & & .867 & .916 & .808 \\
Male, 65 years old & .908 & .936 & .868 & & .854 & .898 & .797 \\
Male, 70 years old & .889 & .917 & .853 & & .836 & .881 & .783 \\
Female, 60 years old & .928 & .966 & .861 & & .876 & .924 & .832 \\
Female, 65 years old & .907 & .942 & .857 & & .857 & .892 & .812 \\
Female, 70 years old & .886 & .920 & .841 & & .836 & .869 & .790 \\
\hline
\end{tabular}

Source: Authors' calculations as described in the text. Sample consists of fourteen companies with data provided by Annuity Direct, Ltd. See source note to table 9.1 above.

and women of different ages in the compulsory U.K. annuity market. Results for the average annuity payout are given as a simple average across the firms in our sample. We also provide the EPDV using average payouts for the three highest and three lowest annuity payout firms in our sample. The results show that the cost of buying an inflation-protected annuity in the United Kingdom is about 5 percent of the annuity premium. In addition, we find that the EPDV of a nominal annuity contract purchased in conjunction with a qualified retirement-saving plan is 5 percent higher than that for a real annuity. While the EPDV for nominal annuities is approximately 90 percent of the premium cost, the analogous EPDV for real annuities is about 85 percent. This difference in EPDVs might explain Diamond's (1997) claim that most annuitants in the United Kingdom elect nominal rather than real annuities.

Some of the apparent "cost" of inflation protection may arise from adverse selection across various types of annuities. If annuitants who anticipate that they will live much longer than the average annuitant tend to purchase real annuities because their real payout stream is backloaded, then mortality rates for those who buy real annuities may be lower than those for nominal annuity buyers. We do not know whether such mortality differences actually explain the payout differences between nominal and real annuities.

Our estimates of the EPDV of nominal annuity payouts in the United Kingdom are somewhat higher than analogous estimates for nominal annuity products in the United States at roughly the same date. For example, Poterba and Warshawsky (2000) report that the average EPDV on U.S. nominal annuity contracts available to sixty-five-year-old men in 1998 (using the population mortality table) was 84 percent for annuities purchased through qualified retirement-saving plans. The lower U.S. payout may re- 
flect differences in the degree of mortality selection, relative to the population as a whole, in the "qualified" (U.S.) and "compulsory" (U.K.) annuity markets.

Table 9.2 also suggests that there are systematic patterns in the money'sworth values across age groups for both nominal and real annuities in the U.K. market. The EPDV declines as a function of the annuitant's age at the time the annuity is purchased. One possible explanation for this pattern may be that those who retire later tend to have lower mortality rates than those who retire earlier. Age at retirement and age at annuity purchase may be linked more closely in the compulsory annuity market than in the noncompulsory market. We suspect that many compulsory annuity buyers purchase their annuities when they retire, even though current U.K. rules do not require such purchases.

The results shown in table 9.2 indicate that, for a retiree of given age/ sex characteristics, there is frequently a 10 percent difference between the average annuity payout from the firms offering the highest payout annuities and those offering the lowest payouts. Such dispersion is consistent with earlier evidence, such as MPWB (1999), suggesting substantial pricing differences in the U.S. market for nominal annuities. This price dispersion raises the question of how potential annuitants choose among the various annuity products. In the U.S. case, MPWB (1999) report little correlation between factors such as the credit rating of the insurance company offering the annuity and the level of the annuity's payout.

In sum, we draw two lessons from the widespread availability of indexlinked annuities in the U.K. annuity market. The first is that it is possible for private insurers to develop and offer real annuity products. This is surely easier in a nation with a well-developed market for index-linked bonds. The second lesson is that, on the basis of the current prices of nominal and real annuities, the costs of obtaining inflation insurance are less than 5 percent of the purchase price of a nominal annuity contract.

\subsection{Real Annuities in the United States: TIAA-CREF and ILONA}

The U.S. individual annuity market differs from that in the United Kingdom in that virtually all annuity products are nominal annuities. Individuals can purchase a variety of products with a graded payout structure so that the nominal value of their payouts (and, for low-enough inflation rates, the real value of payouts) is expected to rise over time. Only two annuity products of which we are aware promise some degree of inflation protection. The first is the "Freedom" CPI-indexed income annuity, offered by the Irish Life Company of North America (ILONA), and the second is the inflation-linked bond account annuity, offered by TIAA-CREF. In this section, we describe how these products work, their current prices and payouts, and the degree to which they provide inflation protection 
for annuity buyers. We also note that, since Treasury inflation-protection securities (TIPS) were introduced to the U.S. market only recently, additional insurers may offer real annuities as familiarity with these new assets grows. Insurance companies can hedge the inflation risk associated with these price-level-indexed annuity products by purchasing TIPS bonds.

\subsubsection{The ILONA Real Annuity}

Irish Life PLC, an international insurance firm headquartered in Dublin, offers index-linked annuities in the United States through the Interstate Assurance Company, which is a division of Irish Life of North America. Interstate is a well-regarded company: it had assets of $\$ 1.3$ billion, and it received a AA rating from Duff and Phelps, an A rating from A. M. Best, and a AA - rating from Standard and Poor's in 1996. The indexed-annuity product from ILONA is the "Freedom CPI-Indexed Income Annuity." The annuity payout rises annually in step with the increase in the prior year's CPI. Annuity benefits from the Freedom CPI-indexed income annuity cannot decline in nominal terms, even if the CPI were to fall from year to year. The minimum purchase requirement for the ILONA annuity product is $\$ 10,000$, and the maximum purchase is $\$ 1$ million. The annuity is available to individuals between the ages of sixty-five and eighty-five. There are various payout options, including simple-life annuities, annuities that provide a fixed numbers of years of payouts for certain, and "refund annuities." These annuity products are available both as individual and as joint-and-survivor annuities. Although ILONA offers this real annuity product in the United States, the agent we contacted indicated that thus far no sales of these annuities have been recorded.

Data were obtained on the monthly payouts offered by ILONA's indexed and nominal single-premium immediate annuities for men and women aged sixty-five, seventy, and seventy-five, assuming a premium of $\$ 1$ million in each case. We also obtained data on joint-and-survivor annuities with 100 percent survivor benefits. Policies purchased in mid-1998 offered a monthly payout on a real annuity at the start of the annuity contract about 30 percent smaller than the payout on a nominal annuity issued to the same individual. Table 9.3 shows that, for men at age sixtyfive, the ratio of real to nominal payouts is 69 percent. For women at sixtyfive, the ratio is 66 percent, potentially reflecting the longer life expectancy and therefore greater backloading that occurs with a real rather than a nominal annuity for women rather than for men.

To determine the payouts relative to premium cost for these annuities, we calculate the EPDV of annuity payouts for each of the ILONA policies quoted using a procedure similar to that described above. Interest and mortality rates differ somewhat relative to the U.K. calculations. For discount factors in our EPDV calculations, we use the nominal yield curve for zero-coupon U.S. Treasury bonds. We start from the term structure of 
Monthly Annuity Payouts on Single-Premium Annuity Products Offered by ILONA in the U.S. Market, 1998

\begin{tabular}{lccc}
\hline $\begin{array}{l}\text { Annuitant Age } \\
\text { and Product }\end{array}$ & $\begin{array}{c}\text { Male, Single-Life } \\
\text { Annuity (\$) }\end{array}$ & $\begin{array}{c}\text { Female, Single-Life } \\
\text { Annuity (\$) }\end{array}$ & $\begin{array}{c}\text { Joint-and-Survivor } \\
\text { Annuity with Full } \\
\text { Survivor Benefits (\$) }\end{array}$ \\
\hline Age 65, unindexed & 7,452 & 6,720 & 6,068 \\
Age 65, indexed & 5,149 & 4,432 & 3,849 \\
Age 70, unindexed & 8,520 & 7,543 & 6,663 \\
Age 70, indexed & 6,262 & 5,332 & 4,549 \\
Age 75, unindexed & 10,075 & 8,825 & 7,594 \\
Age 75, indexed & 7,833 & 6,643 & 5,552 \\
\hline
\end{tabular}

Note: All payouts correspond to an initial purchase of $\$ 1$ million. Data were provided by Irish Life of North America (ILONA). For further details, see the text.

yields for zero-coupon Treasury "strips" and work out the pattern of monthly interest rates implied by these yields under the simpleexpectations theory of the term structure. Data on the zero-coupon yield curve are published in the Wall Street Journal, and we use information from the beginning of June 1998. Because we do not know the precise date at which ILONA offered the annuities that we are pricing, and in the light of the absence of transactions in this annuity market, we select the term structure for the first week of June 1998 as an approximate guide to discount rates in mid-1998. When evaluating the EPDV of the ILONA real annuity, we use the implied short-term real interest rates that can be derived from the term structure of real interest rates on TIPS in early June 1998.

With regard to survival patterns, we have access to two distinct mortality tables for the United States. The first, developed by the Social Security Administration's Office of the Actuary and reported in Bell, Wade, and Goss (1992), applies to the entire population. We update this mortality table to reflect the prospective mortality rates of a sixty-five-year-old (or seventy- or seventy-five-year-old) purchasing an annuity in 1998. For example, in estimating the money's worth of an annuity for a sixty-five-yearold in 1998, we use the projected mortality experience of the 1933 birth cohort. A second set of projected mortality rates corresponds to that relevant to current annuitants. MPWB (1999) develop an algorithm that combines information from the annuity 2000 mortality table (described in Johansen [1996]), the older 1983 individual annuitant mortality table, and the projected rate of mortality improvement implicit in the difference between the Social Security Administration's cohort and period mortality tables for the population. This algorithm generates projected mortality rates for the set of annuitants purchasing annuity contracts in a given year. It is worth noting that the population and annuitant mortality rates differ. For instance, MPWB (1999) report that the 1995 annual mortality rate for annuitants aged sixty-five to seventy-five was roughly half that for the gen- 
Expected Present Discounted Value of Annuity Payouts, Freedom InflationIndexed Annuities Offered by ILONA, 1998

\begin{tabular}{lcccc}
\hline & $\begin{array}{c}\text { Male } \\
\text { Annuitant, } \\
\text { Age 65 }\end{array}$ & $\begin{array}{c}\text { Male } \\
\text { Annuitant, } \\
\text { Age 75 }\end{array}$ & $\begin{array}{c}\text { Female } \\
\text { Annuitant, } \\
\text { Age 65 }\end{array}$ & $\begin{array}{c}\text { Female } \\
\text { Annuitant, } \\
\text { Age 75 }\end{array}$ \\
\hline $\begin{array}{l}\text { Calculations using population } \\
\text { mortality table: }\end{array}$ & & & & \\
$\quad \begin{array}{l}\text { Nominal annuity } \\
\text { Real annuity }\end{array}$ & .864 & .830 & .889 & .887 \\
$\begin{array}{l}\text { Calculations using annuitant } \\
\text { mortality table: }\end{array}$ & .702 & .720 & .708 & .762 \\
$\begin{array}{l}\text { Nominal annuity } \\
\text { Real annuity }\end{array}$ & & & & .966 \\
\hline
\end{tabular}

Note: Each entry shows the expected present discounted value of annuity payouts using the algorithm described in the text. See note to table 9.3 above.

eral population. This mortality differential generates a substantially larger EPDV of annuity payouts with the annuitant rather than the population mortality table.

Table 9.4 reports EPDV calculations for Irish Life real and nominal annuities. (All EPDV calculations use pretax annuity payouts and beforetax interest rates. MPWB [1999] show that pretax and posttax EPDV calculations for U.S. nominal annuities yield similar results.) For nominal annuities valued using the population mortality table, the EPDV of payouts is approximately eighty-five cents per premium dollar for men and eighty-nine cents for women. These values are slightly higher than the average EPDV values based on nominal annuities described in A. M. Best's annuity survey of June 1998, as reported in Poterba and Warshawsky (2000). Using the annuitant mortality table for nominal annuities, the EPDV is larger: approximately ninety-eight cents per premium dollar for men and ninety-seven cents for women.

We next turn to EPDV results for the ILONA real annuity, and we see that the value per dollar of premium is much lower than for the nominal annuity. For instance, a sixty-five-year-old man purchasing a real annuity would expect an EPDV of 70 percent, versus 86 percent for the nominal annuity. At other ages, a similar pattern applies: the money's worth for real annuity products is typically $15-20$ percent lower than that for nominal annuities. The fact that inflation protection adds more than 15 percent to the annuity's cost may explain the limited demand for this product in the United States.

\subsubsection{Annuities Linked to the CREF Index-Linked Bond Account (ILBA)}

In May 1997, the College Equities Retirement Fund (CREF) launched a new investment account that was intended to appeal to those who are 
saving for retirement as well as to retirees receiving annuity payouts. This product, called the CREF Inflation-Linked Bond Account (ILBA), followed from the federal government's decision to issue TIPS on 29 January 1997. TIAA-CREF (1997a) indicated that its new inflation-linked account was expected to be useful for providing participants with "another investment option that can enhance portfolio diversification and mitigate the long-term impact of inflation on their retirement accumulations and benefits." The fund's goal was described, in TIAA-CREF (1997b), as seeking "a long-term rate of return that outpaces inflation, through a portfolio of inflation-indexed bonds and other securities."

The CREF inflation-linked bond account has grown slowly since its inception. At the end of September 1998, the account had attracted investments of only $\$ 131$ million, making it the smallest of all the retirement funds offered by TIAA-CREF. To place this amount in context, on the same date the CREF stock fund held $\$ 96.9$ billion, the TIAA traditional annuity fund held $\$ 94.3$ billion, and all other TIAA-CREF retirement funds combined held about $\$ 25$ billion. Most of the funds held in the ILBA are in the accounts of TIAA-CREF active participants rather than retirees, and as such they are still accumulating rather than drawing down assets.

To describe the inflation protection that an annuity linked to the CREF ILBA provides, we need to provide some background on the structure of this account, on the basic structure of variable-annuity products, and on the specific operation of the CREF variable annuity.

\section{The CREF Index-Linked Bond Account}

TIAA-CREF (1998b) explains that the ILBA "invests mainly in inflation-indexed bonds issued or guaranteed by the US government, or its agencies and instrumentalities, and in other inflation-indexed securities" with foreign securities capped at 25 percent of the assets. At present, the ILBA holds 98 percent of its assets in U.S. government inflation-linked securities and 2 percent in short-term investments maturing in less than one year. In principle, the fund's asset allocation could become broader in the future, with corporate inflation-indexed securities and those issued by foreign governments potentially being included as well as money market instruments. Expenses total thirty-one basis points annually. This expense ratio is lower than many mutual and pension fund expense levels, but it is as high as other, more actively managed CREF accounts such as the stock account (thirty-one basis points) and the bond market account (twentynine basis points) (see www.tiaa-cref.org).

The ILBA has no sales, surrender, or premium charges. Participants may elect this account as one of several investment vehicles into which new retirement contributions may be made and/or into which existing assets from other TIAA-CREF accounts may be transferred. As with other CREF accounts, the participant is limited to one transfer per business day 
Table 9.5

Total Return, 1 January 1998-31 December 1998, by

TIAA-CREF Account (\%)

\begin{tabular}{lr|lr}
\hline CREF Accounts & & TIAA Accounts & \\
\hline Inflation-linked bond account & 3.48 & Traditional annuity & 6.71 \\
Growth account & 32.89 & Real estate account & 8.07 \\
Stock account & 22.94 & Personal annuity stock index & 23.84 \\
Equity index account & 24.12 & account & \\
Social choice account & 18.61 & & \\
Global equities account & 18.58 & & \\
Bond market & 8.60 & & \\
Money market & 5.45 & & \\
\hline
\end{tabular}

Source: www.tiaa-cref.org, various pages.

in or out of the account during the accumulation phase. The ILBA may be used as a vehicle for accumulating retirement assets, or it can be used to back the payment stream for a variable-payout annuity. Most of our interest focuses on the second function.

The ILBA account is marked to market daily, meaning that asset values fluctuate and the account could lose money. For example, if real interest rates rose owing to a decline in expected inflation, bond prices could fall. As the fund prospectus (TIAA-CREF 1998a) points out, in such an event, the inflation-linked bond fund's total return would then not actually track inflation every year. This is a key feature of the ILBA, and it means that the account does not effectively offer a real payout stream to annuitants who purchase variable-payout annuities tied to the ILBA.

Real interest rate changes are not the only source of variation in ILBA returns. If the principal value of inflation-linked bonds changes in response to inflation shocks, perhaps because investors infer something about the future of real interest rates from inflation news, this would also affect the returns on the ILBA. Similarly, changes in the definition of the CPI might affect the ILBA return. Both these issues also arise with respect to direct investments in Treasury inflation-protection securities (TIPS). The ILBA return for 1998 was 3.48 percent. Table 9.5 illustrates that this made it the lowest-earning fund of all the tax-qualified accounts offered by TIAA-CREF in 1998.

\section{Variable Annuities: General Structure}

An annuity with payouts that rise and fall with the value of the CREF ILBA is a special case of a variable-payout annuity. The key distinction between a fixed annuity (including a graded fixed annuity with a prespecified set of changing nominal payouts over time) and a variable annuity is that the payouts on a variable annuity cannot be specified for certain at the beginning of the payout period. Rather, a variable annuity is defined by an initial payout amount, which we denote $A(0)$, and an "updating 
rule" that relates the annuity payout in future periods to the previous payout and the intervening returns on the portfolio that backs the variable annuity.

To determine the initial nominal payout on a single-life variable annuity per dollar of annuity purchase, the insurance company solves an equation like

$$
1=\sum_{j=1}^{T} \frac{A(0) \cdot P_{j}}{(1+R)^{j}},
$$

where $R$ is the variable annuity's "assumed interest rate" (AIR) or the "annuity valuation rate" as in Bodie and Pesando (1983). $T$ is the maximum potential life span of the annuitant. This expression would require modification if the annuity guaranteed a fixed number of payments for certain, regardless of the annuitant's longevity, or if there were other specialized features in the annuity contract. This expression ignores expenses and other administrative costs associated with the sales of annuities or the operation of insurance companies.

The annuity-updating rule depends on the return on the assets that back the annuity, which we denote by $z_{t}$, according to

$$
A(t+1)=A(t) \cdot\left(1+z_{t}\right) /(1+R) .
$$

The frequency with which payouts are updated varies across annuity products, and there is no requirement that the payout be updated every time it is paid. One could, for example, have an annuity with monthly payouts but quarterly updating.

In designing a variable annuity, the assumed interest rate $(R)$ is a key parameter. Assuming a high value of $R$ will enable the insurance company to offer a large initial premium, but, for any underlying portfolio, the stream of future payouts will be more likely to decline as the assumed value of $R$ rises. Equation (4) clearly indicates that an individual who purchases a variable annuity will receive payouts that fluctuate with the nominal value of the underlying portfolio.

\section{Specific Provisions of the CREF ILBA-Backed Annuity}

When a TIAA-CREF participant terminates employment, he or she can begin receiving retirement benefits. The participant then decides how to manage the payouts from accumulated retirement accounts. This includes deciding whether to annuitize the retirement assets, how much to annuitize, and whether to use an inflation-linked annuity. (Some employers may restrict their retirees' options.) Benefits are payable monthly, although recipients may elect quarterly, semiannual, and annual payouts as an alternative (TIAA-CREF [1998d] provides more detail on these options). In addition, the participant can choose the form and duration of the payout pattern, subject to minimum-distribution rules set by the IRS. If the par- 
ticipant chooses to annuitize part of his or her accumulation, there are a variety of potential annuity structures, including life annuities, ten- and twenty-year certain-payout annuities, and joint-and-survivor as well as single-life products.

Under TIAA-CREF rules, a CREF participant electing an annuity cannot be more than ninety years of age when he or she initially applies for the annuity. TIAA-CREF (1998b) explains that the applicant must select at least one of the annuity accounts initially for the drawdown phase; thereafter, he or she may switch from one annuity account to another as often as once per quarter. There are restrictions on shifting funds from TIAA to CREF: this must take place over a longer horizon. The choice of annuity fund can be altered, but the form of benefit payout cannot be changed once the annuity has been issued.

In order to understand how CREF annuity payments are determined, it is necessary to define the basic annuity unit value. This is an amount set each 31 March by dividing an account's total funds in payment status by the actuarial present value of the future annuity benefits to be paid out, assuming a 4 percent nominal interest rate and mortality patterns characteristic of existing CREF annuitants. A unisex version of the mortality table for individual annuitants is used when the applicant first files for an annuity "set back for each complete year elapsed since 1986" (see TIAACREF 1998d). The same mortality table is applied to all TIAA-CREF annuity accounts, on the basis of participant mortality experience. Mortality experience is adjusted every quarter.

A newly retired participant seeking to annuitize his retirement sum must have his own accumulation amount translated into an initial annuity amount $(A(0))$, determined by dividing his accumulation by the product of an annuity factor and the basic annuity unit value just described. The annuity factor reflects assumed survival probabilities based on the annuitant's age and an effective annual assumed interest rate (AIR) of 4 percent nominal, explained in TIAA-CREF (1998c).

The participant's initial annuity amount is then adjusted over the life of the annuity contract on either a monthly or an annual basis, depending on the participant's election. The adjustment will reflect the actual fund earnings on a "total return" basis, relative to the 4 percent AIR. Actual investment performance is used to update the annuity values as of 1 May for those electing to have their income change annually or monthly for those electing monthly income changes. Because the investment returns on the underlying accounts affect annuity payouts, these TIAA-CREF annuities are variable-payout annuities.

\section{The Extent of Inflation Protection}

It is evident that a variable-payout annuity linked to the CREF ILBA does not provide a guaranteed stream of real payouts since it is marked 
to market daily. Thus, if the price drops, or if the unit value fails to rise with inflation, the participant's unit value would not be constant in real terms. More important, the CREF annuity may fail to keep up with inflation because of the way in which it is designed. When the first-year annuity payout is set, it assumes the 4 percent AIR mentioned above, which is the same rate used for other CREF annuities. In subsequent years, if the unit value of the account were to rise less than 4 percent, payouts would be reduced to reflect this lower valuation. Consider the experience of 1998, when the total return (after expenses) on the ILBA account was 3.48 percent. Since the AIR for the CREF annuity is 4 percent, an annuity in its second- or later-year payout phase would experience a decline in payout of 0.52 percent. Since the price level rose in 1998, it is clear that the annuity payouts are not constant in real terms. A necessary condition for the payouts on this variable annuity not to decline in real terms would be for the real return on the account, that is, on Treasury inflation-protection securities, to exceed 4 percent. At present, it does not.

The precise extent to which payouts on ILBA-backed variable annuities will vary in real terms in the future is an open question. If the prices of inflation-linked bonds are bid up during high-inflation periods and real interest rates decline at such times, this will partly protect the ILBA account value. One relevant comparison for potential annuitants, however, may be between holding a CREF ILBA-backed variable annuity and purchasing TIPS bonds directly. Two considerations are relevant to such a comparison. First, the TIPS bonds offer a more direct form of inflation protection, although they do not provide any risk sharing with respect to mortality risk. Second, there are tax differences between the two investment strategies. TIPS would be taxable if they were not held in a qualified pension account, while the income from bonds held in the CREF ILBAbacked account is not taxed until the proceeds are withdrawn.

The CREF variable-payout annuity linked to the ILBA would be more likely to deliver a future real payout stream if the AIR on this annuity were set equal to the real interest rate on long-term TIPS at the time when the annuity is purchased. In this case, the return on the bond portfolio would typically equal the AIR plus the annual inflation rate, leaving aside some of the risks of holding indexed bonds, such as changes in the way the CPI is constructed. This would provide a mechanism for delivering something closer to a real annuity payout stream. One difficulty with this approach is that it would make it more difficult for annuitants to take advantage of some of the investment flexibility currently provided by CREF. At present, all CREF annuities assume the same AIR, regardless of the assets that back them. This facilitates conversions from one annuity type to another.

To date, there has been very limited demand for CREF's ILBA-backed variable-payout annuities. This lack of demand raises the perennial ques- 
tion of why retirees are not more concerned about inflation protection. One reason often given is "inflation illusion"; that is, people simply do not understand how inflation erodes purchasing power. Another reason may be that inflation-proof assets are new and that investors have not yet learned how to think about such assets. Hammond (personal communication to O. Mitchell, 10 November 1998) notes that inflation-linked bonds in other countries took some time to become popular after they were introduced: "After a flurry of initial interest, inflation bonds in those countries went through a period of quiescence-low liquidity and little interest. Then, with some sort of trigger-renewed inflation or a strong commitment on the part of central government - the market picked up and people began to figure out what the bonds were good for. In the U.K. this process took about ten years." (See Hammond 1999.) The United States today may be in the early stages of this process.

\subsubsection{Conclusions about Real Annuities in the United States}

Our analysis of the ILONA and TIAA-CREF experience suggests that there is currently no market for genuine real annuities in the United States. While ILONA offers a product that guarantees a real stream of payouts, no one has yet purchased this annuity. This may reflect the fact that the instrument's pricing requires relatively high rates of inflation to generate benefits with EPDVs similar to those of nominal annuities offered by ILONA and other insurers. The inflation-linked bond account offered by CREF has attracted investment funds since it became available in 1997, but the CREF variable annuity with payouts linked to returns on inflationindexed bonds does not guarantee its buyers a constant real payout stream. Although in practice it may come close to delivering a constant real payout, its performance will depend on the as yet uncertain movements in the prices of Treasury inflation-protection securities (TIPS).

\subsection{Asset Returns and Inflation: Another Route to Inflation Insurance}

We now shift from our focus on insurance contracts that explicitly provide a constant real income stream for retirees to consider the possibility of using variable-payout annuities linked to assets other than indexed bonds as an alternative means of avoiding inflation risk. Such variablepayout annuities may reduce the effect of inflation in two ways. First, they may offer higher average returns than the assets that are used in pricing real and nominal annuities. These returns may, of course, come at the price of greater payout variability. Second, the prices of the assets that underlie the variable-payout annuities may move in tandem with the price level. In this case, a variable-payout annuity could provide a form of inflation insurance.

To examine these arguments, we begin by summarizing the well-known 
historical real-return performance of U.S. stocks, bonds, and Treasury-bill investments. We consider an individual who invests $\$ 1$ in cash or in a portfolio of Treasury bills, long-term bonds, or corporate stock. We calculate the real value of an initial $\$ 1$ investment after five, ten, twenty, and thirty years. We first perform this calculation in 1926 so that the thirtyyear-return interval concludes in 1955 . We then repeat the calculation in 1927, 1928, and all subsequent years for which we have enough data to calculate long-term returns. The last year for which we have return information is 1997, so we finish our five-year calculations in 1993, our tenyear calculations in 1988, and so on.

To summarize the results on the real value of each investment, we calculate both the average real value of each investment, averaged across all the years with sufficient data, and the standard deviation of this real return. The results of these calculations appear in table 9.6. The underlying calculations have been done using actual returns on stocks, bills, and bonds over the period 1926-97. For the return after five (thirty) years, there are sixty-six (forty-one) overlapping return intervals. The results presented in table 9.6 show that holding cash worth $\$ 1$ initially would have a real value of only forty-nine cents after twenty years on average. In contrast, a \$1 initial investment in bills or bonds would have increased in real value. For bills, the cumulative real return over twenty years was 1.3 percent, while for bonds it was 16.1 percent.

The last column of table 9.6 shows comparable calculations for corporate stock. Here, the real value of the investment after twenty years would have increased by a factor of 4.5. This implies that an investor who purchased an income stream tied to the total return on the U.S. stock market,

Table 9.6

Real Value of a One-Dollar Investment after Various Periods, 1926-97 Average

\begin{tabular}{lcccc}
\hline & & \multicolumn{3}{c}{ Investment Portfolio } \\
\cline { 3 - 5 } Value after $N$ Years & $\begin{array}{c}\text { Cash (no } \\
\text { investment return) }\end{array}$ & $\begin{array}{c}\text { Treasury } \\
\text { Bills }\end{array}$ & $\begin{array}{c}\text { Treasury } \\
\text { Bonds }\end{array}$ & $\begin{array}{c}\text { Corporate } \\
\text { Stock }\end{array}$ \\
\hline 5 years & 0.864 & 1.036 & 1.128 & 1.477 \\
& $(0.150)$ & $(0.163)$ & $(0.315)$ & $(0.517)$ \\
10 years & 0.729 & 1.047 & 1.233 & 2.214 \\
& $(0.205)$ & $(0.245)$ & $(0.561)$ & $(1.071)$ \\
20 years & 0.490 & 1.013 & 1.161 & 4.569 \\
& $(0.160)$ & $(0.285)$ & $(0.560)$ & $(2.941)$ \\
30 years & 0.356 & 1.033 & 1.112 & 8.679 \\
& $(0.129)$ & $(0.324)$ & $(0.478)$ & $(4.728)$ \\
\hline
\end{tabular}

Note: Each entry shows the mean value of a one-dollar initial investment, in real terms, and the standard error (in parentheses) of this value. Calculations are based on authors' computations using actual realizations of inflation, bill, bond, and stock returns over the period 1926-97, as reported in Ibbotson Associates (1998). 
such as an equity-linked variable annuity, would have the potential to receive a real income stream that is higher late in retirement than at the beginning of retirement. This stands in stark contrast to the declining real value of the payouts on a fixed nominal annuity contract.

The substantial real return on U.S. equities suggests that one method of obtaining partial long-term protection against inflationary erosion of annuity payouts might be to purchase a portfolio of equities and then to link annuity payouts to equity returns. Such a strategy exposes the annuitant to the substantial intrinsic volatility of the equity market and does not guarantee a fixed real return. The higher average return on equities than on bonds nevertheless reduces the probability of a declining real payout stream from the annuity policy.

In practice, however, variable-annuity policies that offer payouts linked to equity returns do not guarantee real payouts that rise as steeply as table 9.6 suggests. This is because the payouts on a variable annuity depend on the performance of the underlying assets relative to the annuity product's assumed interest rate (AIR) ( $R$ in eq. [3]). Therefore, the variable-annuity payout for an equity-linked variable annuity can rise over time only if the equity portfolio returns more than the assumed value of $R$ used in designing the annuity. Bodie and Pesando (1983) assume that $R$ equals the historical average return on the assets that back the annuity in their hypothetical evaluation of variable-payout annuities. In practice, we have found that nominal $R$ values of 3 or 4 percent per year are common, even for equity-linked variable-payout annuities, in the current annuity market. One should note that, if a variable-payout annuity assumed $R=0$, then the real payouts in table 9.6 would in fact describe the experience of an annuitant since the nominal payout recursion would become $A(t+1)=$ $A(t) \cdot\left(1+z_{t}\right)$.

The high average real return on equities implies that an investor holding U.S. stocks over the last seven decades would have experienced a rising real-wealth profile. But, to study whether this is because equities provide a good inflation hedge, we must explore the way U.S. equity returns covary with shocks to the inflation rate. If stocks generate positive returns when the inflation rate rises unexpectedly, then equities operate as an inflation hedge. The fact that U.S. equities have generated substantial positive returns over the period since 1926 does not provide any information on the correlation between inflation and stock returns.

We investigate the historical covariances between real U.S. stock returns, bond returns, bill returns, and unexpected inflation shocks over two sample periods: 1926-97 and 1947-97. If the real return on a particular asset category is not affected by unexpected inflation, then that asset can serve as a valuable inflation hedge. If the real return on the asset declines when inflation rises unexpectedly, however, then that asset does not provide an inflation hedge. 
The first step in our analysis involves estimating a time series for "unexpected inflation." We do this by estimating fourth-order autoregessive models relating annual inflation $\left(\pi_{t}\right)$ to its own lagged values or to its own lagged values as well as those of nominal Treasury-bill rates $\left(i_{t}\right)$. The basic regression specification is either

$$
\begin{aligned}
\pi_{t}= & \rho_{0}+\rho_{1} \cdot \pi_{t-1}+\rho_{2} \cdot \pi_{t-2}+\rho_{3} \cdot \pi_{t-3}+\rho_{4} \cdot \pi_{t-4} \\
& +\phi_{1} \cdot i_{t-1}+\phi_{2} \cdot i_{t-2}+\phi_{3} \cdot i_{t-3}+\phi_{4} \cdot i_{t-4}+\varepsilon_{i t}
\end{aligned}
$$

or

(5b) $\pi_{t}=\rho_{0}+\rho_{1} \cdot \pi_{t-1}+\rho_{2} \cdot \pi_{t-2}+\rho_{3} \cdot \pi_{t-3}+\rho_{4} \cdot \pi_{t-4}+\varepsilon_{i t}$.

Table 9.7 presents the findings from estimating $(5 a)$ and $(5 b)$ for the two sample periods. Two broad conclusions emerge from the table. First, there is a great deal of persistence in inflation. The sum of the four coefficients on lagged inflation for the period 1926-97 is .773, while for the period 1947-97 it is .732. There is somewhat greater inflation persistence in the early years of the sample than in the postwar period. We experimented with extending the length of the lag polynomials in (5a) and (5b). While the fourth-order inflation lag in both equations shows a coefficient that is statistically significantly different from zero, higher lagged values were never statistically significant.

Second, the incremental explanatory power of lagged Treasury-bill

Table 9.7

\begin{tabular}{|c|c|c|c|c|}
\hline $\begin{array}{l}\text { Explanatory } \\
\text { Variable }\end{array}$ & $\begin{array}{c}\text { Lagged Inflation } \\
\text { Only, 1930-97 }\end{array}$ & $\begin{array}{l}\text { Lagged Inflation } \\
\text { and Bills, 1930-97 }\end{array}$ & $\begin{array}{l}\text { Lagged Inflation } \\
\text { Only, 1947-97 }\end{array}$ & $\begin{array}{l}\text { Lagged Inflation } \\
\text { and Bills, 1947-97 }\end{array}$ \\
\hline Constant & $\begin{array}{l}.008 \\
(.005)\end{array}$ & $\begin{array}{l}.010 \\
(.006)\end{array}$ & $\begin{array}{l}.009 \\
(.006)\end{array}$ & $\begin{array}{l}.005 \\
(.006)\end{array}$ \\
\hline Inflation $(t-1)$ & $\begin{array}{l}.706 \\
(.113)\end{array}$ & $\begin{array}{c}.666 \\
(.124)\end{array}$ & $\begin{array}{l}.647 \\
(.100)\end{array}$ & $\begin{array}{l}.566 \\
(.106)\end{array}$ \\
\hline Inflation $(t-2)$ & $\begin{array}{r}-.146 \\
(.142)\end{array}$ & $\begin{array}{r}-.086 \\
(.148)\end{array}$ & $\begin{array}{r}-.161 \\
(.119)\end{array}$ & $\begin{array}{r}-.127 \\
(.120)\end{array}$ \\
\hline Inflation $(t-3)$ & $\begin{array}{r}-.223 \\
(.142)\end{array}$ & $\begin{array}{r}-.208 \\
(.146)\end{array}$ & $\begin{array}{r}-.056 \\
(.118)\end{array}$ & $\begin{array}{r}-.066 \\
(.119)\end{array}$ \\
\hline Inflation $(t-4)$ & $\begin{array}{l}.436 \\
(.112)\end{array}$ & $\begin{array}{c}.447 \\
(.119)\end{array}$ & $\begin{array}{l}.302 \\
(.099)\end{array}$ & $\begin{array}{l}.280 \\
(.103)\end{array}$ \\
\hline Bill yield $(t-1)$ & & $\begin{array}{l}.370 \\
(.340)\end{array}$ & & $\begin{array}{c}.549 \\
(.241)\end{array}$ \\
\hline Bill yield $(t-2)$ & & $\begin{array}{r}-.694 \\
(.470)\end{array}$ & & $\begin{array}{r}-.677 \\
(.328)\end{array}$ \\
\hline Bill yield $(t-3)$ & & $\begin{array}{r}-.129 \\
(.483)\end{array}$ & & $\begin{array}{l}.218 \\
(.338)\end{array}$ \\
\hline Bill yield $(t-4)$ & & $\begin{array}{l}.108 \\
(.338)\end{array}$ & & $\begin{array}{l}.053 \\
(.234)\end{array}$ \\
\hline Adjusted $R^{2}$ & .507 & .500 & .544 & .571 \\
\hline
\end{tabular}

Estimates of the Inflation Process for the United States, 1930-97

Source: Authors' calculations using data from Ibbotson Associates (1998). 
Table 9.8

Unexpected Inflation and Real Asset Returns, United States, 1926-97

\begin{tabular}{lccccccc}
\hline & \multicolumn{3}{c}{$1930-97$ Sample } & & \multicolumn{3}{c}{ 1947-97 Sample } \\
\cline { 2 - 3 } Inflation Process & Bills & Bonds & Stocks & & Bills & Bonds & Stocks \\
\hline Bills and inflation & -0.827 & -1.702 & -1.582 & & -0.580 & -3.442 & -4.326 \\
& $(0.137)$ & $(0.389)$ & $(0.804)$ & & $(0.174)$ & $(0.650)$ & $(1.077)$ \\
Inflation only & -0.864 & -1.672 & -1.560 & & -0.387 & -2.515 & -4.271 \\
& $(0.128)$ & $(0.378)$ & $(0.783)$ & & $(0.170)$ & $(0.664)$ & $(0.975)$ \\
5-year nonoverlapping & 0.191 & -1.522 & -1.969 & & & \\
$\quad$ returns, inflation only & $(0.437)$ & $(0.657)$ & $(0.670)$ & & & \\
\hline
\end{tabular}

Note: Each entry corresponds to the coefficient $\lambda_{i}$ in the regression equation

$$
R_{i t}=\alpha+\lambda_{i} \cdot \pi_{u, t}+\varepsilon_{i t},
$$

where $R_{i t}$ denotes the real return on asset $i$ in period $t$, and $\pi_{u, t}$ denotes the unexpected inflation rate. Estimates are based on authors' analysis of data in Ibbotson Associates (1998), as described in the text.

yields is relatively small after we have controlled for lagged inflation. Bill rates have somewhat greater explanatory power in the postwar period than in the full sample period. Because most of the estimated coefficients on bill rates for both sample periods are statistically insignificant, however, the unexpected inflation series calculated from specifications (5a) and (5b) are likely to yield similar estimates of the correlation between unexpected inflation and asset returns.

We estimate unexpected inflation $\left(\pi_{u, t}\right)$ by computing the residuals from either $(5 a)$ or $(5 b)$. These unexpected inflation series incorporate some future information in each case because the coefficients are estimated over the full sample period. We then use these time series as the explanatory variables in regression models in which real stock, bond, or bill returns are the dependent variables:

$$
R_{i t}=\alpha+\lambda_{i} \cdot \pi_{u, t}+\varepsilon_{i t} .
$$

Table 9.8 shows the coefficient estimates for $\lambda_{i}$ from regression models estimated for the two sample periods.

The results provide no evidence to suggest that stocks or bonds have been inflation hedges during the last seventy years. For both these asset categories, a 1 percentage point increase in the rate of unexpected inflation is associated with a decline of more than 1 percent in bond and in stock values. The estimated negative effects are larger, although somewhat less precisely estimated, for the period 1947-97 than for the longer sample. As noted above, the two unexpected inflation series, one corresponding to a lagged-inflation-only predicting equation, the other corresponding to the augmented specification with lagged Treasury-bill returns as well, produce very similar results when they are included on the right-hand side of equation (6). 
We also find evidence that unexpected inflation reduces real Treasurybill returns. The effect on these returns is more muted than that on bond and stock returns, and, for both sample periods, we find that a 1 percentage point increase in unexpected inflation reduces the real return on Treasury bills by less than 1 percentage point. Nevertheless, for both sample periods, we reject the null hypothesis that real Treasury-bill returns are unaffected by inflation surprises.

The finding that unexpected inflation is negatively correlated with real asset returns is broadly consistent with previous research. For example, Barr and Campbell (1996) show that the real interest rate on U.K. indexed bonds appears to covary negatively with inflation. Evans (1998) surveys a number of other empirical papers, using data from several nations and various methodologies, all of which reach similar conclusions. Our findings for equities are consistent with Bodie (1976), who suggested that using equities to hedge inflation risk requires a short position in equities.

One question that some might raise about the results presented in table 9.8 concerns the focus on one-year return horizons. It is possible that the high-frequency correlation between unexpected inflation and asset returns differs from the lower-frequency correlation. Boudoukh and Richardson (1993) present some evidence for both the United States and the United Kingdom suggesting that the nominal return on corporate equities moves together with inflation at long horizons. To explore this issue, we repeated our analysis using real returns and unexpected inflation over five-year intervals. We confined our analysis to the sample period 1926-97 and used an AR(2) model to construct an estimate of unexpected inflation. We focused on nonoverlapping five-year intervals, which provided twelve observations for estimating equation (6). The last row of table 9.8 presents the results. They continue to show a negative correlation between real stock and bond returns and unexpected inflation. The only change relative to the previous findings is that unexpected inflation no longer has a negative effect on real Treasury-bill returns.

Our empirical results therefore suggest that the inflation-hedging properties of equities and long-term bonds are limited. Nevertheless, as Siegel (1998) and others have noted, over long horizons, equities have typically generated very substantial positive real returns. This appears to be the result of a high average real return on equities rather than a positive correlation between equity returns and unexpected inflation. A substantial body of research has tried to explain the high average return on equities in the United States during the last century as a function of the correlation between equity returns and various risk factors. This has proved difficult and has become known as the "equity-premium puzzle."

The weak high-frequency correlation between equity returns and inflation is a challenge to many traditional models of asset pricing since equities represent a claim on real assets that hold their value in real terms. Prior studies have suggested a number of potential explanations for the 
absence of a positive correlation between inflation and equity returns. Feldstein (1980) focused on the interaction of inflation and corporate tax rules, while Modigliani and Cohn (1979) emphasized inflation illusion among equity investors. We are not aware of any empirical evidence that provides clear guidance for choosing among these explanations.

\subsection{Evaluating the Utility Gains from Access to Real Annuities}

We have not yet considered how valuable inflation protection might be for a retiree seeking to annuitize his retirement resources. We now address this issue by estimating a potential annuitant's "annuity equivalent wealth" from access to real, nominal, and equity-linked variable-payout annuities. We focus on equity-linked variable annuities because equities have historically earned higher expected returns than other assets and because the findings presented above showed that, while bills offer some inflation protection, their expected return has historically been very small. Bonds offer limited inflation protection and substantially lower average returns, at least historically, than stocks.

The annuity-valuation framework employed is closely related to that developed in Kotlikoff and Spivak (1981) and MPWB (1999). These two studies examine the utility gain that a representative individual receives from access to actuarially fair annuity markets. Brown (1999) provides empirical evidence suggesting that this framework has predictive value for explaining whether individuals plan to annuitize the balance that they accumulate in a defined-contribution plan. In this section, we compare the utility gains associated with access to different types of annuities. Our findings provide some guidance on the value to retirees of real versus nominal annuities.

\subsubsection{Analytic Framework for Evaluating Alternative Annuities}

Our basic algorithm estimates the utility gains accruing to someone with no annuity who is offered a fixed, nominal annuity on actuarially fair terms, a real annuity on fair terms, and an equity-linked variable annuity. To illustrate our procedure, we explain how we calculate an individual's "annuity equivalent wealth" when this individual is offered access to a fixed nominal annuity. We assume that this individual purchases such an annuity at age sixty-five, which we normalize to be "year 0." This individual receives an annuity payment in each year that he remains alive, and his optimal consumption path will be related to this payout. The annuity payout at age $a\left(A_{a}\right)$ depends on wealth at the beginning of retirement $\left(W_{\text {ret }}\right)$, potentially on the value of the assets underlying the annuity when the annuitant is age $a$, and on the annual annuity payout per dollar of premium payment $(\theta)$. In the case of a fixed nominal annuity, the nominal value of $A_{a}$ is independent of age: $A_{a}=\theta \cdot W_{\text {ret }}$. For simplicity, we do not consider the taxes paid on annuity payouts or the taxes on the returns to 
nonannuity assets. MPWB (1999) find that the relative utilities of different annuity products are not sensitive to the inclusion of tax rules.

To find the actuarially fair ratio of nominal annuity payouts to premium cost, $\theta$, for a sixty-five-year-old male in 1995, we use the Social Security Administration's cohort life table for men born in 1930. We define actuarial fairness as equality of the premium cost and the EPDV of annuity payouts. This definition ignores the potentially important role of administrative expenses that are incurred by the insurance company offering the annuity, so it is likely to overstate the payouts that would be available in actual annuity markets. We find $\theta$ from the following equation:

$$
1=\sum_{j=1}^{50} \frac{\theta \cdot P_{j}}{[(1+r)(1+\pi)]^{j}} .
$$

In this expression, $P_{j}$ denotes the probability of a sixty-five-year-old retiree remaining alive $j$ years after retirement, $r$ denotes the annual real interest rate, and $\pi$ is the annual inflation rate. For computational simplicity, we use years rather than months in our annuity valuation and continue to assume that no one survives beyond age 115 , so $P_{50}=0$.

After finding the actuarially fair payout value, we compute the expected discounted value of lifetime utility that would be associated with the consumption stream generated by this nominal annuity. To do this, we assume that individuals have additively separable utility functions of the following form:

$$
U=\sum_{j=1}^{50} P_{j} \cdot \frac{\left[\left(\frac{C_{j}}{(1+\pi)^{j}}\right)^{1-\beta}-1\right]}{(1-\beta) \cdot(1+\rho)^{j}} .
$$

For this functional form, the parameter $\beta$ is the individual's coefficient of relative risk aversion. This parameter also determines the degree of intertemporal substitution in consumption. The nominal consumption flow $\left(C_{j}\right)$ is deflated by the price index $(1+\pi)^{j}$.

We consider a first case in which our sixty-five-year-old uses all his resources to purchase an annuity contract and a second case in which he purchases an annuity with half his resources. In the second case, we assume that the other half of the individual's resources is invested in a real annuity. This case can be thought of as describing the retiree's choice problem when he has both an individual account balance that can be annuitized and a substantial real retirement annuity like that offered by the current social security system. As explained by Hurd (1987) and MPWB (1999), the marginal value of an increase in annuitization is greater when fewer resources are already annuitized.

We assume that the retiree has wealth at age sixty-five of $W_{\text {ret }}$, and, 
for illustrative purposes, we focus on the case in which the retiree has no preexisting annuity wealth. We find the optimal consumption path for someone who receives a nominal annuity of $\theta W_{\text {ret }}$ per period. For such an individual, the budget constraint at each age $a$ is given by

$$
W_{a+1}=\left(W_{a}+\theta W_{\mathrm{ret}}-C_{a}\right) \cdot[(1+r)(1+\pi)] .
$$

This specification makes the standard assumption that nominal interest rates rise point for point with inflation even though our previous results call this assumption into question. The retiree with budget constraint (9) also faces an initial condition on wealth after purchasing the annuity: $W_{0}=0$. It is possible that the retiree will save some of the payouts from the annuity contract, and thereby accumulate wealth, in the early years of retirement.

Equation (9) assumes that the investment opportunity set for the retiree consists of a nominal bond that offers a fixed real return $r$. The utility gains from purchasing an annuity are likely to depend on the set of portfolio options that investors have outside their annuity contract. Campbell and Viceira (1998) present some evidence on the optimal structure of portfolios at different points in the life cycle for investors who have access to nominal and real bonds. Extending our framework to allow for more realistic portfolio structure is a natural direction for further work.

We compute the retiree's lifetime expected utility by solving for his optimal consumption path $\left\{C_{a}\right\}$ using stochastic dynamic programming, where the stochastic component of the problem arises from uncertainty regarding date of death. The result is lifetime expected utility as a function of wealth at retirement, $U^{*}=U^{*}\left(W_{\text {ret }}\right)$, for the case in which the retiree has access to a nominal annuity contract.

When the retiree does not have access to an annuity market, his problem is to maximize the utility function (8) subject to the budget constraint and initial condition:

$$
W_{a+1}=\left(W_{a}-C_{a}\right) \cdot[(1+r)(1+\pi)]
$$

and

$$
W_{0}=W_{\text {ret }} .
$$

The optimal consumption path in this case yields a value of lifetime expected utility, again as a function of wealth at retirement, $U^{* *}=U^{* *}\left(W_{\mathrm{ret}}\right)$, for a retiree with no access to an annuity market.

The annuity-equivalent wealth is the amount of wealth that a retiree 
needs - if he does not have access to an annuity market - to achieve the lifetime utility level that he can attain with access to an annuity market. We assume full annuitization when the annuity market is available. We note in passing that, in some cases, full annuitization does not yield the highest possible level of lifetime expected utility. Hurd $(1987,1989)$ shows that some individuals can be overannuitized when their optimal consumption path is constrained by the annuity-income flow. This could happen to individuals with high discount rates relative to the interest rate. Nevertheless, our calculations compare full annuitization with no annuitization.

Formally, annuity-equivalent wealth $W_{\text {aew }}$ satisfies the equation

$$
U^{* *}\left(W_{\text {aew }}\right)=U^{*}\left(W_{\text {ret }}\right)
$$

We use a numerical search algorithm to find the value of $W_{\text {aew }}$ that satisfies this equation. Since the longevity insurance associated with an annuity makes the individual better off, $W_{\text {aew }}>W_{\text {ret }}$. The retiree requires more wealth to achieve a given retirement utility level when he does not have access to a nominal annuity market than when he does.

When we report the annuity-equivalent wealth in our results below, we normalize $W_{\text {aew }}$ by $W_{\text {ret }}$, and we report $W_{\text {aew }} / W_{\text {ret. }}$. This makes our calculations directly comparable to those in Kotlikoff and Spivak (1981). Our annuity-equivalent-wealth calculations differ, however, from MPWB's (1999) estimates of the amount of wealth that individuals would be prepared to give up in order to invest their remaining wealth in actuarially fair annuities. In MPWB (1999), the central focus is on the divergence between the EPDV of annuity payouts and the purchase price of annuity contracts. Because the EPDV is less than the purchase price, the natural question to ask is what fraction of their wealth individuals would rationally forgo in order to obtain an annuity.

In the present paper, we follow Kotlikoff and Spivak (1981) in asking how much additional wealth an individual would need to be as well off without access to an annuity market as with it. Our choice of this approach, rather than the wealth-equivalent approach of MPWB (1999), was largely motivated by computational concerns. In the present setting, we search for $W_{\text {aew }}$ in a relatively simple problem, where the only source of uncertainty is mortality risk. Real interest rates are certain in our benchmark case with the budget constraint in (10a). If we used either the nominal or the variable-annuity cases as our benchmark, we would need to search for $W_{\text {aew }}$ in a problem that includes both mortality risk and inflation risk. This substantially slowed our numerical solution algorithm.

In simple environments without any preexisting annuities, the annuity- 
equivalent wealth (AEW) that we report is simply a transformation of the wealth-equivalent (WE) measure in MPWB (1999): WE = 1/AEW. Thus, if we find that a retiree requires 1.5 times as much wealth to achieve a given utility level without access to nominal annuities as with them, we could also interpret this as implying that the retiree would be prepared to give up 33 percent of his wealth $(.50 / 1.5)$ if he did not have a nominal annuity in order to obtain access to one. When the retiree has some preexisting annuity wealth, however, the relation becomes more complex, and this relation holds approximately but not exactly.

Our analysis of the annuity-equivalent wealth for a nominal annuity generalizes immediately to the case of a real annuity or a variable-payout annuity. For an actuarially fair real annuity, we determine the annual payout per dollar of premium, $\theta^{\prime}$, from the expression

$$
1=\sum_{j=1}^{50} \frac{\theta^{\prime} \cdot P_{j}}{(1+r)^{j}} .
$$

This expression is analogous to (7), but the discount factor involves only real interest rates, and the numerator involves only real payouts. As in the discussion above, we find the optimal consumption profile for a consumer who purchases such an annuity, and we then find the annuity-equivalent wealth associated with access to a real annuity.

We also consider the utility consequences of being able to purchase variable-payout annuity products, in particular the case in which annuity payouts are indexed to an underlying portfolio of common stocks. To compute the actuarially fair payout on such variable annuities, we assume that a risk-neutral insurance company offers a variable annuity with an initial payout $\theta^{\prime \prime}$ determined by

$$
1=\sum_{j=1}^{50} \frac{\theta^{\prime \prime} \cdot P_{j}}{(1+R)^{j}} .
$$

In this expression, $R$ is the AIR for the variable-annuity product. The payout in the first period of the annuity purchase is therefore

$$
A_{v}(0)=\theta^{\prime \prime} \cdot W_{\text {ret }} \text {. }
$$

The nominal payout on the variable annuity is determined in subsequent periods by the recursion

$$
A_{v}(t+1)=A_{v}(t) \cdot(1+z) /(1+R),
$$

where $z$ denotes the nominal return on the equity portfolio.

In considering the equity-linked variable annuity, it is essential to recognize that the initial payout on the annuity policy is increasing in the AIR. The appeal of the equity-linked variable annuity arises from this higher 
initial payout stream and from the higher average returns earned on the assets invested in the variable annuity.

\subsubsection{Calibration of Annuity-Equivalent Wealth}

To carry out the annuity-equivalent-wealth calculations described in the previous subsection, we must calibrate the lifetime-utility function, the survival probability distribution, and the distributions for inflation and real returns on the assets that might be held in portfolios backing variablepayout annuities. All results will assume that the utility discount rate $\rho$ is equal to the riskless interest rate $r$.

\section{Risk Aversion}

The parameter $\beta$ in equation (8) represents the household's degree of risk aversion and its willingness to engage in intertemporal substitution in consumption. This risk-aversion parameter is an important determinant of the gains from annuitization when the real value of annuity payouts in future periods is uncertain because of stochastic asset returns or stochastic inflation.

Most empirical studies that attempt to estimate a value of relative risk aversion from household consumption patterns find values close to unity, which corresponds to log utility. Laibson, Repetto, and Tobacman (1998) summarize this literature. Mehra and Prescott (1985), however, note that much higher levels of risk aversion are required to rationalize the presence of the large premium of corporate equity returns over riskless-bond returns in historical U.S. data. It is difficult to reconcile the empirical evidence of low risk aversion and the existence of the large historical equity premium. Recent work based on survey questions about household tolerance of risk, reported in Barsky et al. (1997), also suggests values higher than unity. In the light of this dispersion of findings, we present calculations using risk-aversion coefficients of $1,2,5$, and 10 . In their related study of the utility gains from annuitization, Baxter and King (chap. 10 in this volume) consider an even wider range of risk-aversion values, ranging from 2 to 25 . We are inclined to place the most emphasis on our findings with risk-aversion coefficients between 1 and 5, but we present findings using $\beta=10$ to provide evidence on the robustness of our findings.

\section{Survival Probabilities}

The mortality process that we use in our analysis corresponds to the population mortality table supplied by the Social Security Administration. We use a cohort life table with projected future mortality rates since we are interested in an annuity purchased by someone who is currently of retirement age. We use a 1930 birth cohort table to study a sixty-five-yearold male, so our calculations effectively describe someone who was considering purchasing an annuity in 1995. 


\section{The Inflation Process}

We use historical data from the period 1926-97 to calibrate the stochastic process for inflation. The average value of inflation over this period is 3.2 percent per year. We assume that the inflation rate in each "year" takes one of six values: $-10.2,-1.44,1.75,3.82,9.06$, or 18.2 percent. The respective probabilities of these inflation outcomes are assumed to be .01, $.19, .3, .3, .19$, and .01 . These inflation values correspond approximately to the first, tenth, thirty-fifth, sixty-fifth, ninetieth, and ninetieth-ninth percentiles of the annual inflation distribution for the years 1926-97, and they imply an average annual inflation rate of 3.2 percent. We have devoted special attention to the extreme tails of the inflation distribution to make sure that our analysis captures the possibility of a very high inflation period since we might otherwise overstate the value of an annuity that is fixed in nominal terms.

We consider two cases for the inflation process, corresponding to different assumptions about the degree of inflation persistence over time. The first case treats each annual inflation rate as an independent draw from our six-point distribution. This approach to modeling inflation tends to understate the long-run variance of the real value of fixed nominal payments and thus serves as a lower bound on the effect of inflation. Our empirical findings in the last section demonstrate clearly that inflation is a highly persistent process.

In the second case, we incorporate persistence by allowing inflation to follow a stylized AR(1) process. In the first period, inflation is drawn from the same six-point distribution as in the i.i.d. scenario. In later periods, however, there is a probability $\gamma$ that $\pi_{t+1}$ will be equal to $\pi_{t}$ and a probability $1-\gamma$ of taking a new draw from the six-point distribution. An attractive feature of this approach is that $\gamma$ is equal to the AR(1) coefficient in a regression of inflation on its one-period lagged value, and thus $\gamma$ can be parameterized using historical inflation data. Using U.S. historical data from the period 1926-97, the AR(1) coefficient for inflation is equal to 0.64 , and this is the value of $\gamma$ that we use in modeling a persistent inflation process.

The benefit of avoiding the inflation risk is shown by comparisons between our annuity-equivalent-wealth values when retirees have access to actuarially fair nominal annuity markets and actuarially fair real annuity markets. Our measure is related to, but not equivalent to, Bodie's (1990) analysis of the value of inflation insurance as the cost of purchasing a call option on the consumer price index. His approach generates the cost of producing an inflation-indexed income stream, while our approach focuses on the consumer valuation of such an income stream. 


\section{Risky Asset Returns}

Our analysis assumes that investors have access to riskless real returns of 3 percent per year $(r=.03)$. While this return is higher than the average return on "riskless" Treasury bills over the period 1926-97, it is lower than the current return on long-term TIPS. We think of TIPS as the riskless asset with respect to retirement saving and therefore use a higher return than the historical real return on Treasury bills. We further assume that inflation raises the nominal return on this riskless asset so that the real return is unaffected by inflation. This is tantamount to assuming that the investor is holding an indexed real bond.

When we consider variable annuity products backed by portfolios of risky securities, we must specify both the mean return associated with these securities and the variability of returns around this mean. Higher mean returns on the portfolios that back variable-payout annuities will make these products more attractive to potential annuitants, while greater risk will reduce their attractiveness.

We consider a variable-payout annuity backed by a broad portfolio of common stocks. Table 9.9 presents historical information on real returns and the standard deviation of real returns for U.S. stocks, bills, and bonds over the period 1926-97. This table is another way of presenting the information in table 9.6 above on real returns over different horizons. We assume throughout that the standard deviation of real returns on equities equals its historical average value of 20.9 percent per year.

In computing the annuity-equivalent wealth for an equity-backed variable annuity, we consider two different assumptions with regard to the mean real return on equities. First, we assume a 6 percent real return (i.e., a 3 percent premium over the indexed-bond return). This assumption about the equity premium is substantially smaller than the historical average differential between stock and bond returns, but it is designed to be conservative. Second, we consider a case with a 9 percent real return on equities, which translates to a 6 percent premium above the real bond.

Mean Real Returns and Standard Deviations of Real Returns, 1926-97 (\%)

\begin{tabular}{lccccc}
\hline & \multicolumn{2}{c}{$1926-97$} & & \multicolumn{2}{c}{$1947-97$} \\
\cline { 2 - 3 } \cline { 5 - 6 } & $\begin{array}{c}\text { Mean } \\
\text { Real Return }\end{array}$ & $\begin{array}{c}\text { Standard } \\
\text { Deviation }\end{array}$ & & $\begin{array}{c}\text { Mean } \\
\text { Real Return }\end{array}$ & $\begin{array}{c}\text { Standard } \\
\text { Deviation }\end{array}$ \\
\hline Treasury bills & 0.73 & 4.17 & & 0.87 & 2.64 \\
Long-term Treasury bonds & 2.57 & 10.53 & & 2.01 & 11.13 \\
Equities & 9.66 & 20.46 & & 9.93 & 16.95 \\
\hline
\end{tabular}

Source: Authors' tabulations using data from Ibbotson Associates (1998). 
This is still a smaller equity premium than historical returns suggest, but it yields a real return on equities close to the historical average. The extent to which historical real returns on corporate stock provide guidance on prospective returns is an open issue (for divergent views, see Campbell and Shiller [1998] and Siegel [1998]). In both cases, we assume an AIR on the variable annuity equal to the expected return on the underlying portfolio, following the approach of Bodie and Pesando (1983).

In order to account for the variability in returns, we again use a discrete six-point approximation to capture the distribution of real equity returns. Specifically, we constructed a distribution of the equity excess return over the period 1926-97. By subtracting off the mean excess return and then adding in our assumed 6 or 9 percent mean return, we constructed our distribution of equity returns. This approach allows us to alter our assumption about the mean equity premium over the riskless rate while holding the variance of equity returns at historical levels. We pick points from the first, tenth, thirty-fifth, sixty-fifth, ninetieth, and ninety-ninth percentiles of the distribution and use the probabilities $.01, .19, .3, .3, .19$, and .01 for these draws. For the case of a 6 percent mean real return, the corresponding points in the return distribution are $-.475,-.182,-.036$, $.156, .306$, and .506 . For the case of a 9 percent mean real return, the entire distribution of returns is shifted up by .03 . Real equity returns are modeled as independent across time. This does not allow for any possible variance compression at long horizons.

\subsubsection{Results on the Valuation of Real versus Nominal Annuities}

Table 9.10 reports our estimates of the annuity-equivalent wealth for real and nominal annuities. The first three columns report results for the case with no preannuitized wealth, when the potential annuitant places all his wealth in an annuity. Columns 4-6 explore the case in which the potential annuitant already holds half his net worth in a real annuity such as social security. To interpret the results, first consider the case in which the potential annuitant has a logarithmic utility function $(C R R A=1)$. In this case, the annuity-equivalent wealth is 1.502 for a fixed real annuity. This implies that an individual would be indifferent between having $\$ 1$ in a real annuity or $\$ 1.50$ in nonannuitized wealth. Note that the annuityequivalent wealth for this individual is 1.451 in the case of i.i.d. inflation and 1.424 in the case of persistent inflation. These results suggest that a real annuity is more valuable than a nominal annuity and more so when the inflation process is more persistent.

For a real annuity, the annuity-equivalent wealth is monotonically increasing with the level of risk aversion. When the CRRA coefficient is 10, for example, the annuity-equivalent wealth rises to 2.004, meaning that an individual is indifferent between $\$ 2$ of nonannuitized wealth and $\$ 1$ in wealth that can be invested in a real annuity. For fixed nominal annuities 
Table 9.10 Annuity-Equivalent Wealth for Real and Nominal Annuities

\begin{tabular}{|c|c|c|c|c|c|c|}
\hline \multirow[b]{2}{*}{$\begin{array}{l}\text { Coefficient of } \\
\text { Relative Risk } \\
\text { Aversion }\end{array}$} & \multicolumn{3}{|c|}{$\begin{array}{c}\text { Individual with No Preexisting } \\
\text { Annuity Wealth }\end{array}$} & \multicolumn{3}{|c|}{$\begin{array}{c}\text { Individual with Half of Initial Wealth } \\
\text { in Preexisting Real Annuity }\end{array}$} \\
\hline & $\begin{array}{c}\text { Real } \\
\text { Annuity }\end{array}$ & $\begin{array}{l}\text { Nominal } \\
\text { Annuity: } \\
\text { i.i.d. } \\
\text { Inflation }\end{array}$ & $\begin{array}{l}\text { Nominal } \\
\text { Annuity: } \\
\text { Persistent } \\
\text { Inflation }\end{array}$ & $\begin{array}{l}\text { Real } \\
\text { Annuity }\end{array}$ & $\begin{array}{l}\text { Nominal } \\
\text { Annuity: } \\
\text { i.i.d. } \\
\text { Inflation }\end{array}$ & $\begin{array}{c}\text { Nominal } \\
\text { Annuity: } \\
\text { Persistent } \\
\text { Inflation }\end{array}$ \\
\hline 1 & 1.502 & 1.451 & 1.424 & 1.330 & 1.304 & 1.286 \\
\hline 2 & 1.650 & 1.553 & 1.501 & 1.441 & 1.403 & 1.366 \\
\hline 5 & 1.855 & 1.616 & 1.487 & 1.623 & 1.515 & 1.450 \\
\hline 10 & 2.004 & 1.592 & 1.346 & 1.815 & 1.577 & 1.451 \\
\hline
\end{tabular}

Source: Authors' calculations. The annuity-equivalent wealth for the nominal annuity is calculated under the assumption that inflation takes one of six possible values, roughly capturing the distribution of inflation outcomes over the period 1926-97. Inflation shocks are independent across periods in the i.i.d. case and follow a stylized AR(1) process in the persistent-inflation case. For further discussion, see the text.

in the presence of uncertain inflation, this monotonic relation between the annuity-equivalent wealth and the level of risk aversion does not hold. This is because there are two effects of risk aversion that work in opposite directions in the case of inflation uncertainty. The first is that higher risk aversion leads one to value an annuitized payout more highly because the annuity eliminates the risk of outliving one's resources. This is the only effect present when examining real annuity products. The second factor, which works in the opposite direction, is that more risk-averse individuals have a greater dislike for the uncertainty introduced into the real annuity stream by stochastic inflation. Increased variability in the real value of the annuity flows reduces utility, and this effect is largest for those with the highest degree of risk aversion.

At low levels of risk aversion, the first effect dominates, and the annuityequivalent wealth for fixed nominal annuities is rising with risk aversion. For example, moving from CRRA $=1$ to $\mathrm{CRRA}=2$, the annuityequivalent wealth increases from 1.451 to 1.553 in the i.i.d.-inflation case and from 1.424 to 1.501 in the persistent-inflation case. However, as risk aversion increases further, the second effect becomes stronger, and the annuity-equivalent wealth begins to decrease with risk aversion.

The annuity-equivalent wealth values described above provide information on the amount of incremental wealth that individuals would require to be made as well off as if they had access to annuities, assuming that they have no preexisting annuity coverage. The difference between the annuityequivalent-wealth values for real and nominal annuities provides information on how valuable a real annuity is relative to a nominal annuity. For example, to achieve a given utility target in a world with i.i.d. inflation, a nominal annuity is worth 5.1 percent of wealth less than a real annuity 
$(1.502-1.451)$. At higher risk-aversion levels, the differential between real and nominal annuities rises even further. When CRRA $=5$ and inflation is i.i.d., the nominal annuity is worth 23.9 percent of wealth less than the real annuity. In the case that is most unfavorable to nominal annuities, that of persistent inflation and a risk-aversion coefficient of 10 , access to a real annuity is equivalent to doubling one's initial wealth, while access to a nominal annuity is equivalent to only a one-third increase in wealth.

The results are attenuated when we consider the annuitization decision of an individual who already holds a substantial amount of his wealth in a preexisting real annuity. Such a potential annuitant would require a smaller increment to wealth to achieve the same utility level-without access to a private annuity market - that he could obtain with such access. For example, a consumer with a risk-aversion coefficient of unity would require only a 33 percent increment to his wealth to be made as well off as if he had a real annuity, compared to 50 percent in the case when no wealth was previously annuitized. The presence of a preexisting real annuity offers the potential annuitant some insurance against very low consumption values. This accounts for the diminished value of an additional privately purchased annuity.

When the annuity option is a nominal rather than a real annuity, the effect of having a preexisting real annuity is more complex. When inflation draws are independent across years, the results are similar to those for real annuities: the annuity-equivalent wealth from annuitization declines when there is a preexisting real annuity. When we allow for a persistent-inflation process, however, along with very high values of risk aversion, the results change. For example, when CRRA $=10$, the annuity-equivalent wealth is higher when the potential annuitant has preannuitized wealth than when he does not. This is because we have assumed that the preexisting annuity is a fixed real annuity, which provides insurance against the annuitant ever experiencing very low values of real income and therefore consumption. Thus, the utility cost of having high and persistent inflation erode the value of a nominal annuity is reduced, and the potential annuitant's willingness to purchase a nominal annuity rises.

\subsubsection{Results on the Valuation of Variable Annuities}

Table 9.11 reports our findings for the case of equity-linked variablepayout annuities. We assume that the AIR for such annuities corresponds to the average real equity return that is built into our calculations. Once again, we report two panels, corresponding to different degrees of preexisting annuitization. The first column reports results when the average return on equities exceeds that on bonds by 3 percent, so the real return on equities averages 6 percent. For an individual with logarithmic utility in this return environment, an equity-linked variable-payout annuity generates a higher utility level than a real annuity does. In the case of no preex- 
Annuity-Equivalent Wealth for Equity-Linked VariableAnnuity Products

\begin{tabular}{|c|c|c|c|c|}
\hline \multirow{3}{*}{$\begin{array}{l}\text { Coefficient } \\
\text { of Relative } \\
\text { Risk } \\
\text { Aversion }\end{array}$} & \multicolumn{2}{|c|}{ No Preexisting Annuities } & \multicolumn{2}{|c|}{$\begin{array}{l}\text { Preexisting Real Annuity } \\
\text { Equal to Half of Initial Wealth }\end{array}$} \\
\hline & Real Stock & Real Stock & Real Stock & Real Stock \\
\hline & Return $6 \%$ & Return $9 \%$ & Return $6 \%$ & Return $9 \%$ \\
\hline \multicolumn{5}{|c|}{ Annuity-Equivalent Wealth } \\
\hline 1 & 1.623 & 2.024 & 1.567 & 1.953 \\
\hline 2 & 1.499 & 1.901 & 1.570 & 1.957 \\
\hline 5 & 0.921 & 1.355 & 1.443 & 1.789 \\
\hline 10 & 0.331 & 0.622 & 1.261 & 1.563 \\
\hline \multicolumn{5}{|c|}{ Annuity-Equivalent Wealth Ratio, Variable Annuity/Real Annuity } \\
\hline 1 & 1.081 & 1.348 & 1.178 & 1.468 \\
\hline 2 & 0.908 & 1.152 & 1.090 & 1.358 \\
\hline 5 & 0.496 & 0.730 & 0.889 & 1.102 \\
\hline 10 & 0.165 & 0.310 & 0.695 & 0.861 \\
\hline
\end{tabular}

Source: Authors' calculations, as described in the text. The calculations in the bottom panel show the ratio of the annuity-equivalent wealth from the upper panel to the analogous annuity-equivalent wealth from holding a real annuity with an assumed real return of 3 percent. The underlying annuity-equivalent wealth values for the real annuity case are shown in table 9.10, cols. 1 and 4, above. A ratio greater that one indicates that the variable annuity is more valuable than a real annuity. Ratios less than one indicate that the real annuity is more valuable.

isting annuities, the annuity-equivalent wealth for the variable annuity, 1.623 , is higher than that for the real annuity in table 9.10 above (1.502). For higher levels of risk aversion, however, a variable annuity with a mean return of 6 percent is worth less than a real annuity. In fact, an individual placing 100 percent of his wealth in a variable annuity can actually be made worse off than he would be if not annuitizing at all when his degree of risk aversion is high enough and the equity distribution is highly uncertain. This is indicated by annuity-equivalent wealth values below unity.

The lower panel of table 9.11 reports the ratio of the annuity-equivalent wealth with an equity-linked variable annuity to that with a real annuity. When these entries are greater than one, a potential annuitant would prefer a variable annuity to a fixed real annuity. When the entry is less than one, the individual would be better off in a real annuity. In the case of $\log$ utility, the individual always prefers an equity-linked variable-annuity product. At higher risk-aversion levels, however, the fixed real annuity usually dominates. The same pattern is evident when we allow a higher real return on equities. For three of the eight combinations of risk aversion and real equity returns that we considered, a potential annuitant who was preparing to annuitize all his wealth would prefer the variable to the real annuity. For five of the eight combinations, this outcome also emerges in 
the case with a preexisting real annuity. Variable annuities are relatively more attractive with preexisting real annuities than without. This is again because the preexisting real annuity provides a minimum consumption floor below which the annuitant will not fall. Therefore, the risk of a very low consumption state resulting from a series of negative equity returns is reduced.

These findings suggest that, for rates of risk aversion commonly cited in the consumption literature, and for plausible rate-of-return assumptions, potential annuitants would often prefer to purchase variable annuities with payouts linked to equity returns rather than real annuities offering constant purchasing power throughout the annuity period. Even when the expected real return on stocks is only 3 percent, the extra return afforded by the variable annuity more than compensates potential annuitants for the inflation risk that they bear. This is particularly evident when the annuitant is already endowed with a real annuity that represents a substantial share of net wealth because, in that case, the risk of very low consumption as a result of adverse variable-annuity returns is mitigated.

Our results on variable annuities are probably sensitive to our restriction of the menu of assets that investors can hold outside the variable annuity: we do not allow investments in corporate stock except through the variable-annuity channel. Exploring the robustness of our findings to relaxation of this constraint is an important topic for future work.

\subsection{Conclusions and Further Directions}

We have provided new evidence on the functioning of existing real annuity markets and on the potential role of nominal, real, and variablepayout annuities in providing income security to retirees. Three conclusions emerge from the analysis.

First, private insurers can and do offer real annuities to potential annuitants. Although at present there is virtually no U.S. market for real annuity products, in the United Kingdom indexed government bonds have been available for nearly two decades, and, there, indexed annuities are widely available. From the standpoint of an annuity purchaser, the cost of purchasing a real rather than a nominal annuity in the United Kingdom is at most 5 percent of the annuity principal.

Second, real returns on a broad-based portfolio of U.S. stocks have historically outpaced inflation by a substantial margin. While extrapolating from historical returns must be done with caution, the past returns suggest that there may be benefits for retirees from investing part of their annuity wealth in a variable-annuity product with returns linked to the returns on corporate stock. Nevertheless, our analysis of the correlation between unexpected inflation and equity returns suggests that the appeal of an equity-linked variable annuity is primarily the result of the equity premium rather than a strong positive correlation between inflation shocks 
and equity returns. At least at high frequencies, U.S. equities do not appear to offer an inflation hedge.

Third, consumers place a modest value on access to real rather than nominal annuities. We consider our results for retirees with a coefficient of relative risk aversion of two as a "benchmark" case. We find that, if a potential annuitant could not purchase a nominal annuity, he would need roughly 1.5 times as much wealth to achieve the same lifetime utility level that he could obtain with his given wealth and access to a nominal annuity. He would need 1.65 times as much wealth to achieve the utility level that he could obtain if he had access to a real annuity market. These two findings can be combined to suggest that a retiree with access to a real annuity who loses such access would be made worse off by approximately the same amount as he would be if he lost 10 percent of his wealth. Consumers also value access to variable-payout equity-linked annuities, although their demand for such products is quite sensitive to their degree of risk aversion. For moderately risk-averse consumers, with coefficients of relative risk aversion of 2 or less, the annuity-equivalent wealth for an equity-linked variable annuity may be greater than that for a real annuity. This finding obtains even when we assume that the average annual real return on equities is only three hundred basis points higher than the real return on riskless bonds.

These findings bear on two concerns that are raised in connection with social security reform plans that include individual accounts. One is that insurers might not be able to bring to market products providing inflation and longevity protection. Our evidence suggests that this is, in fact, not a concern in the two countries that we have examined. Both have government-issued inflation-indexed bonds that can be used to back private inflation-indexed annuities.

A second concern is that, given a choice, retirees might use their individual account funds to purchase nominal rather than inflation-indexed annuities. This is perceived as a problem to the extent that it exposes retirees to the risk of consumption losses in old age. Our model suggests that the expected utility losses associated with the purchase of a nominal rather than a real annuity are modest. It also implies that consumer demand for inflation-linked annuities in an individual accounts system would be positive, although the extent to which our stylized model describes actual consumer behavior is an open issue. The demand for real annuities is greatest among the most risk-averse consumers. It is also increasing in the degree of persistence of inflation shocks. When inflation is serially independent, the annuity-equivalent wealth for a nominal annuity is higher than when inflation is highly persistent. This is because, conditional on the average inflation rate, the risk of experiencing high and persistent inflation poses a greater threat to real retirement consumption than the risk of a shorter-lived period of high inflation.

The demand for real annuities also tends to be lower for households 
with a substantial endowment of annuitized wealth. This would include any remaining real defined-benefit promises offered to retirees under a restructured social security system. We estimate that the annuity equivalent wealth of a real annuity is about 5-8 percent less for a consumer holding half his wealth in social security than for one having no real annuity at all. Moore and Mitchell (2000) show that older Americans currently hold close to half their retirement wealth in real social security annuities. This may explain the limited current demand for real annuity products in the United States. If the social security system were changed in a way that reduced the importance of CPI-indexed real annuity payouts, the demand for privately provided annuity products might increase substantially.

Our examination of the interplay between annuity choice, inflation protection, and portfolio risks raises a number of issues that could productively be explored in future work. One pertains to the use of more complex annuity products than the ones considered here. We have not investigated "graded nominal payout products," discussed by Biggs (1969) and King (1995). While graded policies do not offer inflation protection per se, they do provide annuitants with an opportunity to backload their real annuity payouts. Annuity-equivalent wealth values from annuitization in graded policies, relative to that for fixed nominal or real annuities, would be straightforward to calculate in our framework.

A more difficult issue for future research concerns the set of portfolio options available to the individuals considering annuitization and the extent to which such households have access to assets other than riskless bonds. One reason for our result that investors find equity-linked annuities valuable is that our models assume that investors can access the equity market only by using variable annuities. It may be realistic to assume that some low-income and low-net-worth households accumulating retirement resources in an individual accounts system do not hold stock in any other way. For higher net-worth households with greater financial sophistication, this assumption is less appropriate. Extending the current analysis to allow for a richer portfolio structure on the part of potential annuitants is an important direction for further work.

\section{References}

Barr, David G., and John Y. Campbell. 1996. Inflation, real interest rates, and the bond market: A study of U.K. nominal and index-linked government bond prices. NBER Working Paper no. 5821. Cambridge, Mass.: National Bureau of Economic Research.

Barsky, Robert B., F. Thomas Juster, Miles S. Kimball, and Matthew D. Shapiro. 1997. Preference parameters and behavioral heterogeneity: An experimental approach in the Health and Retirement Survey. Quarterly Journal of Economics 107 (May): 537-80. 
Bell, Felicitie, A. Wade, and S. Goss. 1992. Life tables for the United States Social Security Area 1900-2080. Actuarial Study no. 107. Washington, D.C.: Social Security Administration, Office of the Actuary.

Biggs, John H. 1969. Alternatives in variable annuity benefit design. Transactions of the Society of Actuaries 21 (November): 495-528.

Blake, David. 1999. Annuity markets: Problem and solutions. Discussion Paper no. PI-9907. Pension Institute, Birkbeck College, London.

Bodie, Zvi. 1976. Common stocks as a hedge against inflation. Journal of Finance 31 (May): 459-70.

. 1990. Inflation insurance. Journal of Risk and Insurance 57, no. 4: 634-45.

Bodie, Zvi, and James Pesando. 1983. Retirement annuity design in an inflationary climate. In Financial aspects of the U.S. pension system, ed. Zvi Bodie and John Shoven. Chicago: University of Chicago Press.

Boudoukh, Jacob, and Matthew Richardson. 1993. Stock returns and inflation: A long-horizon perspective. American Economic Review 83 (December): 134655.

Brown, Jeffrey R. 1999. Private pensions, mortality risk, and the decision to annuitize. NBER Working Paper no. 7191. Cambridge, Mass.: National Bureau of Economic Research.

Budd, Alan, and Nigel Campbell. 1998. The roles of the public and private sectors in the U.K. pension system. In Privatizing social security, ed. Martin Feldstein. Chicago: University of Chicago Press.

Campbell, John Y., and Robert J. Shiller. 1998. Valuation ratios and the long run stock market outlook. Journal of Portfolio Management 24 (winter): 11-26.

Campbell, John Y., and Luis Viceira. 1998. Who should buy long term bonds? NBER Working Paper no. 6801. Cambridge, Mass.: National Bureau of Economic Research.

Diamond, Peter A. 1997. Macroeconomic aspects of social security reform. Brookings Papers on Economic Activity, no. 2:1-87.

Evans, Martin D. 1998. Real rates, expected inflation, and inflation risk premia. Journal of Finance 53 (February): 187-218.

Feldstein, Martin S. 1980. Inflation, tax rules, and the stock market. Journal of Monetary Economics 6 (July): 309-31.

Finkelstein, Amy, and James Poterba. 1999. The market for annuity products in the United Kingdom. NBER Working Paper no. 7168. Cambridge, Mass.: National Bureau of Economic Research.

Friedman, Benjamin, and Mark Warshawsky. 1988. Annuity prices and saving behavior in the United States. In Pensions in the U.S. economy, ed. Z. Bodie, J. Shoven, and D. Wise. Chicago: University of Chicago Press.

. 1990. The cost of annuities: Implications for saving behavior and bequests. Quarterly Journal of Economics 105, no. 1 (February): 135-54.

Gramlich, Edward M. 1996. Different approaches for dealing with social security. Journal of Economic Perspectives 10 (summer): 55-66.

Hammond, P. Brett. 1999. Using inflation-indexed securities for retirement savings and income: The TIAA-CREF experience. In Handbook of inflation-indexed bonds, ed. John Brynjolfsson and Frank J. Fabozzi. New Hope, Pa.: Frank Fabozzi Associates.

Hurd, Michael D. 1987. The marginal value of social security. NBER Working Paper no. 2411. Cambridge, Mass.: National Bureau of Economic Research.

. 1989. The annuity value of social security. In The political economy of social security (Contributions to Economic Analysis, no. 179), ed. B. A. Gustafsson and A. N. Klevmarken. Amsterdam: Elsevier Science.

Ibbotson Associates. 1998. Stocks, bonds, bills, and inflation: 1998 yearbook. Chicago. 
Johansen, R. 1996. Review of adequacy of 1983 individual annuity mortality table. Transactions of the Society of Actuaries 47:101-23.

King, Francis. 1995. The TIAA graded payment method and the CPI. TIAA-CREF Research Dialogues, no. 46. New York, December.

Kotlikoff, Laurence J., and Avia Spivak. 1981. The family as an incomplete annuities market. Journal of Political Economy 89:372-91.

Laibson, David, Andrea Repetto, and Jeremy Tobacman. 1998. Self control and saving for retirement. Brookings Papers on Economic Activity, no. 1:91-196.

Mehra, Rajnish, and Edward Prescott. 1985. The equity premium: A puzzle. Journal of Monetary Economics 15:145-61.

Mitchell, Olivia S., Robert Myers, and Howard Young. 1999. Prospects for social security reform. Philadelphia: University of Pennsylvania Press.

Mitchell, Olivia S., James M. Poterba, Mark Warshawsky, and Jeffrey R. Brown. 1999. New evidence on the money's worth of individual annuities. American Economic Review 89 (December): 1299-1318.

Modigliani, Franco, and Richard Cohn. 1979. Inflation, rational valuation, and the market. Financial Analysts Journal 35 (March): 3-23.

Moore, James, and Olivia S. Mitchell. 2000. Projected retirement wealth and saving adequacy. In Forecasting retirement needs and retirement wealth, ed. O. S. Mitchell, B. Hammond, and A. Rappaport. Philadelphia: University of Pennsylvania Press.

National Academy of Social Insurance (NASI). 1998. Evaluating issues in privatizing social security. Washington, D.C.

Poterba, James M., and Mark Warshawsky. 2000. The costs of annuitizing retirement payouts from individual accounts. In Administrative aspects of investmentbased social security reform, ed. J. Shoven. Chicago: University of Chicago Press. Siegel, Jeremy. 1998. Stocks for the long run. 2d ed. Burr Ridge, Ill.: Irwin Prof.

TIAA-CREF. 1997a. CREF scheduled to launch inflation-linked bond account on May 1, investment forum. New York, spring.

1997b. Introducing the CREF inflation-linked bond account. New York.

1998a. Choosing income options. New York.

1998b. The inflation linked bond account: Supplement of June 1998 to the prospectus of May 1998 for the College Retirement Equities Fund. New York. 1998c. Statement of additional information, May 1998. New York. 1998d. Supplement of June 1998 to the prospectus of May 1998. New York.

Warshawsky, Mark. 1988. Private annuity markets in the United States. Journal of Risk and Insurance 55, no. 3 (September): 518-28.

\section{Comment Mark J. Warshawsky}

In this paper, Brown, Mitchell, and Poterba (BMP) collect interesting institutional information and empirical evidence concerning the operation of, and pricing in, nominal and inflation-indexed individual annuity markets in the United Kingdom and the United States. They also present empirical evidence on the historical correlation of inflation and the nominal

Mark J. Warshawsky is director of research at the TIAA-CREF Institute.

The author thanks John Ameriks, who provided assistance, and Brett Hammond and Gene Strum for helpful conversations. Opinions expressed are not necessarily those of TIAA-CREF. 
returns on the main U.S. asset classes. Finally, BMP show simulation results of an expected-utility model estimating the relative benefits of different annuity types, including nominal fixed, inflation-indexed, and equityindexed variable payouts, in two inflation regimes - independently distributed and a persistent process. By presenting in one location different types of information, empirical evidence, and simulation modeling, this paper is extremely useful, I think, to current policy discussions regarding both individual account proposals for social security reform and pension-plan design. The modeling of the inflation environment is quite novel and sophisticated. My comments follow the flow of the paper, touching on most of its parts, but will focus mainly on the broad question of the investor demand for inflation indexation in annuity products.

In the first section of the paper, BMP assemble a data set based on August 1998 quotes from brokers in the United Kingdom for "compulsory" nominal and inflation-indexed individual annuities. They find that the first-month payout for the inflation-indexed annuities is about 30 percent lower than the payout on the nominal annuity. BMP also find that, while there is substantial variation across insurers in the pricing of all annuity types, variation is higher in the indexed market. Finally, when BMP do the now-familiar "money's-worth" calculation, they find that the expected present discounted value (EPDV) of the payouts from nominal annuities is about 5 percent higher than the expected value of payouts from inflation-indexed annuities, 90 percent compared to 85 percent. They also state that these EPDVs are uniformly higher than the EPDVs for nominal individual annuities in the United States-83.5 percent. BMP also note that EPDVs decline with issue age.

In explaining the money's-worth results, BMP cite adverse selection as a possible explanation; that is, those who expect to live longer will prefer inflation-indexed annuities to nominal annuities (which are of shorter duration), and, as people age, they will have better and more specific information about their own mortality prospects. In addition, in the entirely voluntary U.S. market, adverse selection will be a greater factor than in the compulsory U.K. market. This is a nice, coherent story, and it is bolstered because BMP have calculated their mortality probabilities for the U.K. population correctly; that is, they are using a cohort table that includes expected improvements in mortality, as they used in the calculations for the United States. Mortality improvements will affect the EPDVs of inflation-indexed annuities more than those of nominal annuities. BMP state that their interpretation would be confirmed if evidence were found that those who purchase inflation-indexed annuities have longer life expectancies than those who select nominal annuities. It is worth noting, however, from TIAA-CREF mortality experience that TIAA (fixed) annuitants have slightly longer life expectancies than CREF (variable) annuitants, an outcome that runs somewhat counter to the BMP hypothesis. 
An alternative or additional explanation for the better pricing of nominal as compared to inflation-indexed annuities in the United Kingdom and of U.K. as compared to U.S. annuities, is that there is simply more volume (i.e., demand) in the U.K. nominal annuity market than in other market segments and that therefore that market is more competitive and efficient. The price-variation evidence is consistent with this latter explanation. It is also possible, despite their somewhat breezy assertion that the availability of such indexed bonds has made it possible for U.K. insurers to offer real annuity products without bearing inflation risk, that U.K. insurers bear greater risks in offering real as opposed to nominal annuities and must charge for these risks. In particular, the insurer of a fixed real annuity must bear the risk of unexpected changes in the real interest rate and must also bear inflation risk for those durations not available in the bond market or not covered by futures, options, and swap contracts. Also, because the investments underlying the real annuity market are more predominantly Treasury than corporate securities, there is an opportunity cost from the loss of the corporate bond risk and tax premium, which in the United States runs at almost one hundred basis points.

In the second part of the paper, BMP turn to the nascent U.S. market for inflation-indexed annuities, represented by one company, Irish Life of North America. They compare the monthly payouts of nominal and inflation-indexed annuities issued by Irish Life in the United States and, similar to their finding in the United Kingdom, discover that the first monthly payout from the inflation-indexed annuity is 30 percent smaller than the payout from the nominal annuity. But, unlike their finding in the United Kingdom, when BMP do the money's-worth calculation for the United States, they find that the EPDV for the Irish Life inflation-indexed annuity is much lower (70 percent) than for its nominal annuity ( 86.5 percent). I would suppose that these findings, taken together, are explained by a lower (expected) inflation rate in the United States than in the United Kingdom or a higher real interest rate. Of course, as the only issuer of inflation-indexed annuities in the United States (with no reported issues to date), Irish Life's pricing strategy is probably not too influenced by concerns about competition and will not benefit much from economies of scale and scope. In addition, the benefits of financial technology and market development are not yet available in the United States in the inflationindexed bond arena; there are no swaps, futures, options, or corporatebond issuers yet.

BMP next explain well the CREF inflation-linked-bond-account (ILBA) variable annuity and cite the unique TIAA graded benefitpayment method. They outline the mechanics of how a variable annuity works in the payout phase and appropriately note the importance of the assumed interest rate (AIR), which for all CREF accounts is 4 percent. In this section of the paper, however, I differ somewhat from BMP's inter- 


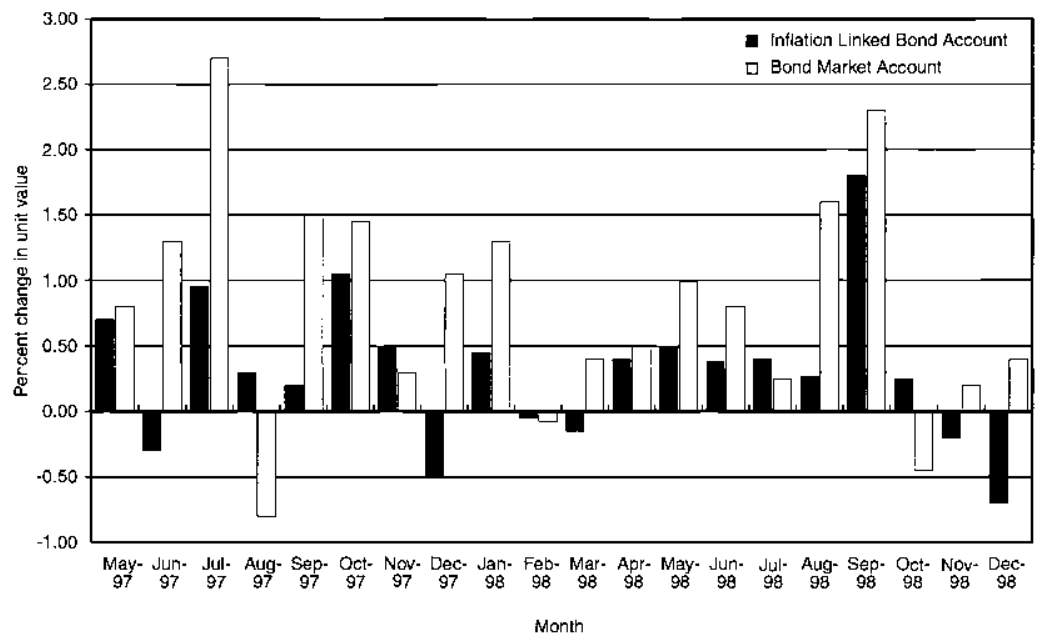

Fig. 9C.1 Month-to-month percent change in unit value for the CREF inflationlinked bond account and the bond account, May 1997-December 1998 Note: May 1997 data are from inception at 1 May 1997.

pretation of the empirical evidence in two areas. It is certainly true that the value of the ILBA is not guaranteed. With the exception of some volatility when the Treasury first issued TIPS and recently, however, the unit value of the ILBA has been quite steady, rising slowly, and is less volatile than the (nominal) CREF bond account. Figure 9C.1 plots the month-tomonth change over the period May 1997-December 1998 in the unit values of the inflation-indexed and nominal bond accounts. The nominal bond account shows a higher return but also higher volatility. Also, I would give a somewhat different interpretation of the relative size of the small ILBA compared to the massive CREF stock account. While it is true that, theoretically, when the ILBA was introduced, all CREF participants could have transferred the entire value of their equity accounts to the ILBA, participant behavior is not so volatile. A more appropriate volume comparison is probably to other newly introduced TIAA-CREF variable accounts; that is done in figure 9C.2. There, we see that, while ILBA asset growth has indeed trailed that of other new accounts, its lower return and lack of investor familiarity probably explain most of the divergence. ${ }^{1}$

BMP state that the ILBA variable annuity could improve its ability to deliver an inflation-indexed payout stream by having the AIR reflect the expected real interest rate on TIPS, perhaps with a haircut for conserva-

1. BMP also comment on the relative expense charges among the CREF accounts. It should be noted that a smaller share of the expense charge is devoted to investment expenses; most of the charge is for administrative costs and is equal across all the accounts. Investment expenses are related to the size of the account as well as to the investment strategy used. 


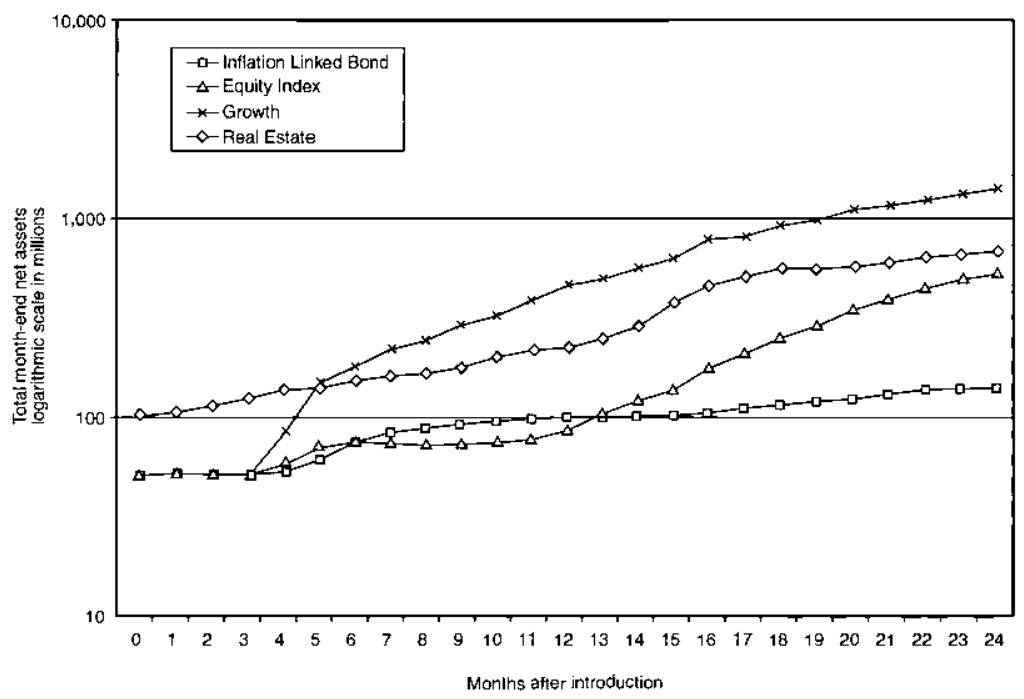

Fig. 9C.2 Net asset growth for new TIAA-CREF accounts

tism; in current conditions, this would suggest an AIR of 3.25 or 3.5 percent. This is a good suggestion if the ILBA is viewed in isolation. Except in the rare cases, however, for most older TIAA-CREF participants, it is probably more sensible for a typical annuitant to have a mix of fixed, equity-indexed variable, and inflation-indexed payout streams; for such a mix, a 4 percent AIR overall probably is more logical. Also, states impose various upper and lower limits on the allowable AIR in a variable annuity, and, therefore, practical business considerations for an insurer issuing annuities in all fifty states may dictate restrictions on feasible AIRs. Finally, contrary to the statement in the paper, and as noted above, TIAA and CREF annuity payouts are priced using two different mortality tables.

In the third section of the paper, BMP examine briefly whether the historical performance of bills, bonds, stocks, and inflation would lead one to believe that the correlation of returns and inflation could let equities serve as a replacement for inflation-indexed securities. While BMP caveat their evidence on this score, their findings are largely negative; equities do not offer an inflation hedge. The historically high return of equities seems to be explained by the equity premium rather than by a correlation with inflation.

In the fourth section of the paper, BMP evaluate the utility gains from, that is, the willingness to pay for, access to inflation-indexed annuities, nominal fixed annuities, and equity-indexed variable annuities. They utilize an expected-utility model with an additively separable utility function and mortality, inflation, and real-return uncertainty. The model is cali- 
brated at various levels of risk aversion found in the literature, general population cohort mortality probabilities, and simple uncorrelated sixpoint distributions of inflation and equity returns related to the historical record (with some adjustments for conservatism and current market conditions). In a major improvement over the version of the paper presented at the conference, BMP also model an inflation process that is persistent from one year to the next. Under these assumptions, BMP find that, at median levels of risk aversion, and with a preexisting real annuity (i.e., social security), the willingness to pay for inflation-indexed annuities is positive but modest. ${ }^{2}$ When inflation is a persistent process, however, the (relative) willingness to pay for inflation-indexed annuities is significantly larger, particularly for higher levels of risk aversion. By contrast, they find that, for plausible risk aversion and rate-of-return assumptions, a significant willingness to pay exists for equity-indexed variable annuities compared to inflation-indexed annuities. This result owes to the superior return on equity investments that more than compensates annuitants for the investment risk that they bear. In this latter comparison of annuity types, BMP apparently did not consider the effect of inflation uncertainty, of either the independently distributed or the persistent-process varieties.

There are several real-world complexities that both decrease and increase the importance of inflation risk relative to the original BMP model; on net, I believe, these complexities make inflation risk more significant than that portrayed in the model. Historical inflation, as measured by the CPI, may be overstated; this is certainly the conclusion of the Boskin Commission and seems to be the consensus of the economics profession, and, indeed, recent actions by the Bureau of Labor Statistics (BLS) are tending to lower the reported inflation rate. By contrast, the CPI measures generally used to measure inflation may understate the rate of inflation relevant to the elderly population most likely to purchase life annuities; because of heavier expenditure weights on medical care and housing, the BLS's experimental CPI-E index indicates that, since 1988, the elderly have been exposed to greater inflation than the rest of the population.

Most important, in contrast to their original simple several-point distribution model of the annual inflation rate, and as they now note, in the real world, inflation has been a persistent process. Once inflation gets started, it is hard to contain, and inflation rates tend to ratchet upward. By contrast, once inflation is low, virtuous expectations take hold, and wage and price pressures are held in check. As shown in table 9C.1, simple regression analysis where the dependent variable is the quarterly percentage change in CPI-U over the period 1950 to the present indicates that

2. It would be interesting to reconcile the results of the BMP simulation model with evidence on the inflation-risk premium extant in the bond market (for a model supporting an estimate that the inflation-risk premium in the United States has been forty-one basis points in the past several decades, see Hammond, Fairbanks, and Durham [1999]). 
Table 9C.1

Regression Results on the Persistence of Inflation

\begin{tabular}{lrccc}
\hline Variable & Coefficient & S.E. & $t$-Statistic & Prob. \\
\hline C & 1.038227 & 0.215709 & 4.813088 & 0.0000 \\
AR(1) & 0.390129 & 0.071770 & 5.435854 & 0.0000 \\
AR(2) & 0.134883 & 0.074733 & 1.804873 & 0.0727 \\
AR(3) & 0.235019 & 0.070494 & 3.333877 & 0.0010 \\
SAR(4) & 0.135348 & 0.075979 & 1.781392 & 0.0764 \\
$R^{2}$ & 0.509494 & Mean dependent variable & 1.001664 & \\
Adjusted $R^{2}$ & 0.499168 & S.D. dependent variable & 0.881805 & \\
S.E. of regression & 0.624049 & Akaike information & 1.920131 & \\
Sum squared residual & 73.99306 & criterion & 2.004054 & \\
Log likelihood & -182.2128 & Schwarz criterion & 49.33878 & \\
Durbin-Watson statistic & 1.971298 & $F$-statistic & 0.000000 & \\
& & prob $(F$-statistic $)$ & $0.00-0.61 i$ & $-0.00+0.61 i$ \\
Inverted AR roots & 0.86 & 0.61 & -0.61 & \\
& $-0.24+0.47 i$ & $-0.24+0.47 i$ &
\end{tabular}

Note: Author's calculations based on data from the U.S. Bureau of Labor Statistics. Dependent variable = INFLPCT; method = least squares; sample = 1950:1-1998:3; no. of observations $=195$.

there is significant autocorrelation in inflation rates; summing the coefficients on lagged terms indicates that the inflation process is, almost, a unit root. Admittedly, the historical period over which this regression is estimated includes some bad experience. Presumably, some lessons were learned, and, therefore, the regression may overstate somewhat the expected persistence of inflation in the future. Nevertheless, I believe that BMP originally leaned too much in the opposite direction, and, therefore, I appreciate the difficult, but ultimately rewarding, work that they recently undertook to model a persistent-inflation process. Temporal persistence effectively increases the risk that inflation represents, particularly to the elderly, whose remaining lifetime is uncertain and whose human capital has effectively been completely depreciated. In fact, it might be interesting to see the effect on their results of a different modeling strategy for inflation; as opposed to an $\mathrm{AR}(1)$ process, they could model independently distributed draws of five- or ten-year inflation rates.

Despite its adverse implication for the level of risk being borne, inflation persistence has a somewhat perverse effect on the psychology of the average investor/plan participant and the demand for inflation indexation. When inflation rates are low and heading downward, as in recent years, the demand for inflation indexation will also be low. Thus, cost-of-living adjustments in private defined-benefit pension plans shrink and disappear. Similarly, the inclusion of inflation indexation in investment and annuity products is a hard sell. By contrast, when inflation rates are rising, inflation indexation becomes more popular. Although this is a bit like buying 
fire insurance after the barn has burned down, pure rationality is not the only influence on human behavior.

BMP end their paper with three conclusions: inflation-indexed annuities can be made available in the private U.S. market, probably at little extra cost; equities, owing to their higher expected return, should have a role in the retirement-income portfolio; and equity-indexed variable annuities offer more to most individuals than inflation-indexed annuities. I agree with all three conclusions, although I believe that the benefits of inflationindexed annuities of some form are probably a bit higher than those stated by BMP and, paradoxically, that it will be a bit more difficult to offer inflation-indexed annuities in the United States than BMP imply.

In summary, Brown, Mitchell, and Poterba have authored a fascinating and important paper. Their analytic conclusions seem to lead to certain policy recommendations and research agendas. In both social security reform and pension-plan design, the best policy is probably to offer a choice of some combination of nominal fixed, inflation-indexed, and equityindexed variable annuities. Further research on the appropriate portfolio mix among these forms in the presence of both inflation and investmentreturn uncertainty would be very helpful.

\section{Reference}

Hammond, P. Brett, Andrew C. Fairbanks, and J. Benson Durham. 1999. Understanding the inflation risk premium. In Handbook of inflation indexed bonds, ed. John Brynjolfsson and Frank J. Fabozzi. New Hope, Pa.: Frank J. Fabozzi.

\section{Discussion Summary}

Andrew Samwick remarked that investors in the model of the paper should be allowed to earn the equity premium outside the annuity. Part of the attractiveness of the variable annuity stems from the high return rather than from the annuity properties. A decomposition would be useful. He further noted that it would be interesting to model the portfolio held outside the annuity as realistically as possible. He suggested using the Survey of Consumer Finances for those purposes. Finally, he argued that incorporating a role for bequests into the analysis would be desirable.

John Campbell followed up on Mark Warshawsky's point about the persistence of the inflation process. He stated that persistence is actually the key to correctly judging inflation risk. In Campbell and Viceira (in press), it was found that, in the postwar period, expected inflation follows a process that has a root near unity. Realized inflation equals of course the 
expected inflation process combined with noise. From these results, cumulative-price-level uncertainty over a long horizon is vastly greater than would be implied by an independent and identically distributed (i.i.d.) process for inflation. People who have looked at the importance of indexation using short-term models (e.g., Viard 1993) have found trivial benefits because there is simply not enough inflation risk over a single quarter or year. Only when one brings in persistence and calculates the cumulative uncertainty over a decade or so do substantial results obtain.

In addition, Martin Feldstein noted that it would be interesting to allow for different regimes for the inflation process, thus distinguishing within the postwar sample the Volcker-Greenspan regime from other less favorable years in a different regime.

Robert Shiller agreed with Campbell's remark and suggested the following rough approximation as an alternative for the Markov modeling strategy in order to capture the persistence of the inflation process. The authors could assume that the inflation rate is 9 percent with probability one in five, not just for one year as is assumed in the paper, but throughout the rest of the retirement. In that case, retirees would value real annuities much more.

Henning Bohn apologized for revisiting the equity-premium puzzle but remarked that an equity-linked account obviously dominates any alternative linked to the bond rate when the equity premium is 3 percent or even 6 percent and the coefficient of relative risk aversion is taken to be only one or two as is reported in table 9.11. Stephen Zeldes concurred and noted that this was related to Samwick's earlier remark.

Deborah Lucas suggested taking into account what other income the elderly have already effectively annuitized. Examples are Medicare annuities in the spirit of Hubbard, Skinner, and Zeldes (1995) and home ownership generating a stream of housing services. Given these effective annuitizations, one would expect the elderly to impute low value to the annuitization of retirement income. Lucas concluded that some sensitivity analysis of the results in the paper with respect to these phenomena would be interesting. Feldstein added that he considers this issue in an earlier paper (Feldstein 1999).

Stephen Ross agreed with what Campbell and Shiller had noted earlier about the inflation process and remarked that correlations between the rate of inflation and the return on the stock market are low. However, the correlation between estimates of long-run expected inflation and the stock market is more substantial.

David Cutler commented that one might want to consider what happens to consumption needs late in life. For instance, it is conceivable that the use of medical care increases. Such needs could be expected to play a role in the design of the optimal annuity. 
In response to the discussion, Jeffrey Brown stated first that he and his coauthors agree with the comments concerning the persistence of the inflation process. He added that they did consider experiments along these lines, by drawing inflation shocks only once every five or ten years, rather than annually, so as effectively to introduce some persistence in a simple manner. Unsurprisingly, this intervention made real annuities more valuable than nominal ones. Brown replied that Bohn's question about the combination of realistic equity premia and low levels of risk aversion was important and required more thought. In response to the comment by Warshawsky that the ratios of real to nominal payouts are similar for the U.S. and the U.K. annuities even though the "money's-worth" calculations give different results for the two countries, Brown made two points. First, mortality in the United Kingdom, based on cohort-specific life tables, was more "favorable." Second, and mainly, the real interest rate was substantially lower in the United Kingdom than in the United States.

Poterba noted that Shiller's suggestion to allow for a nonzero probability of high inflation throughout retirement could be thought of as being the opposite polar case of what was done in the paper and had been pursued in Poterba and Warshawsky (1998). With regard to the equitypremium puzzle and the low level of risk aversion, Brown stated that calculations for higher coefficients of relative risk aversion would be reported in the final version of the paper. Finally, Brown replied to Ross's comment about the low correlation between equity returns and inflation at high frequency, especially using measured inflation, by referring to work done by Boudoukh and Richardson (1993). He noted that a more elaborate analysis requires modeling the expected inflation process, another interesting extension of this research.

\section{References}

Boudoukh, Jacob, and Matthew Richardson. 1993. Stock returns and inflation: A long-horizon perspective. American Economic Review 83, no. 5:1346-55.

Campbell, John Y., and Luis M. Viceira. In press. Who should buy long-term bonds? American Economic Review.

Feldstein, Martin. 1999. Prefunding Medicare. American Economic Review 89, no. 2:222-27.

Hubbard, R. Glenn, Jonathan Skinner, and Stephen P. Zeldes. 1995. Precautionary saving and social insurance. Journal of Political Economy 103, no. 2 (April): 360-99.

Poterba, James M., and Mark Warshawsky. 1998. The costs of annuitizing retirement payouts from individual accounts. Working paper. Massachusetts Institute of Technology, Department of Economics.

Viard, Alan D. 1993. The welfare gain from the introduction of indexed bonds. Journal of Money, Credit, and Banking 25:612-28. 
